\title{
Phytopathology
}

\section{The Genus Phytophthora Anno 2012}

\author{
Laurens P. N. M. Kroon, Henk Brouwer, Arthur W. A. M. de Cock, and Francine Govers
}

First author: Bejo Zaden B.V., Trambaan 2A, 1749 CZ, Warmenhuizen, The Netherlands; second and third authors: CBS-KNAW, Fungal Biodiversity Centre, Uppsalalaan 8, 3584 CT Utrecht, The Netherlands; second author: Microbiology, Utrecht University, Padualaan 8, $3584 \mathrm{CH}$ Utrecht, The Netherlands; and fourth author: Laboratory of Phytopathology, Wageningen University and Centre for BioSystems Genomics, Droevendaalsesteeg 1, 6708 PB Wageningen, The Netherlands.

Accepted for publication 7 December 2011.

\begin{abstract}
Kroon, L. P. N. M., Brouwer, H., de Cock, A. W. A. M., and Govers, F. 2012. The genus Phytophthora anno 2012. Phytopathology 102:348-364.

Plant diseases caused by Phytophthora species will remain an ever increasing threat to agriculture and natural ecosystems. Phytophthora literally means plant destroyer, a name coined in the 19th century by Anton de Bary when he investigated the potato disease that set the stage for the Great Irish Famine. Phytophthora infestans, the causal agent of potato late blight, was the first species in a genus that at present has over 100 recognized members. In the last decade, the number of recognized Phytophthora species has nearly doubled and new species are added almost on a monthly basis Here we present an overview of the 10 clades that are currently distinguished within the genus Phytophthora with special emphasis on new species that have been described since 1996 when Erwin and Ribeiro published the valuable monograph 'Phytophthora diseases worldwide' (35).
\end{abstract}

In the 120 years separating the studies of Heinrich Anton de Bary (24) and the reference monograph 'Phytophthora diseases worldwide' by Erwin and Ribeiro (35), approximately 100 species of Phytophthora have been described in the literature of which 58 were officially recognized (34). In the last decade, the number of validly described Phytophthora species has nearly doubled (Fig. 1) and new species are added almost on a monthly basis. This enormous increase is, on the one hand, due to the availability of more sophisticated tools for species delimitation and, on the other hand, large-scale surveys for the presence of novel Phytophthora species in natural and agricultural settings. In this review we first briefly introduce the basics of classification and identification of

Corresponding author: F. Govers: E-mail address: francine.govers@wur.nl

http://dx.doi.org/10.1094/PHYTO-01-11-0025

This article is in the public domain and not copyrightable. It may be freely reprinted with customary crediting of the source. The American Phytopathological Society, 2012
Phytophthora species. We then present the 10 clades that currently constitute the genus Phytophthora and particularly mention the new Phytophthora species that have been described in the scientific literature since the release of the reference monograph in 1996 (35).

\section{SPECIES IDENTIFICATION AND DELIMITATION}

For a long time identification and classification of species within the genus Phytophthora were based on the key developed by Waterhouse (104), which was later revised and adjusted by Stamps et al. (100). Waterhouse divided the genus into six groups, based on the three sporangium types and two antheridium types. Further criteria used to distinguish species in the pre-molecular era were host range, sporangium morphology, presence or absence of chlamydospores and hyphal swellings, optimal growth temperature, colony and oogonium morphology, and some other criteria. The allocation of an isolate to a particular species was arduous work and required trained experts with a good eye and attention to detail.

The description of a new species was even more challenging, requiring the researcher to be a skilled mycologist able to distinguish the potential new species from all other species, an artist to draw morphological structures by hand, and a classicist to phrase the findings in Latin. Researchers often found discrepancies within a species, for example groups of isolates with much higher optimal growth temperature or aberrant oogonium size. Since the Waterhouse key could often not handle these discrepancies, footnotes were made to justify why the deviating isolates were kept within the species.

Besides morphology, physiological characters have also been used to distinguish species, e.g., temperature-growth relations (100), growth in the presence of malachite green (71), or isozyme patterns (89). When DNA-based identification became common practice, molecular markers were combined with morphological data sets.

For Phytophthora, a variety of DNA-based identification methods has been explored. Amplified fragment length polymorphism fingerprinting, for example, was first used to construct a molecular-genetic linkage map of $P$. infestans (102). Later on AFLP markers as well as microsatellite markers were used as 
high-resolution markers for characterizing Phytophthora isolates and for tracking clonal lineages within populations $(36,38$, 43,66,93). These studies provided invaluable new insights into both population structure within species and variation between species. The exploitation of DNA sequencing provided another big leap forward in knowledge on Phytophthora species. If the sequences for particular genes or DNA regions are identical or nearly identical, the isolates supposedly belong to the same species. If DNA sequences of the same region are available for dozens of species, a phylogeny can be made. Species can then be grouped in clades, consisting of a single common ancestor and all its descendants. The variation revealed by DNA sequencing can also be used for coalescent analysis; a method to trace all alleles of a region of DNA to the most recent common ancestor. In combination with phylogenetic trees, coalescent analysis is particularly useful for delineating species complexes $(41,46)$.

The tendency towards a more phylogenetic species concept based on DNA sequences is most obvious from the Phytophthora Database (http://www.Phytophthoradb.org) in which isolates that form a distinct cluster are considered as representing new species. These species have been labeled as Phytophthora sp. xxxx, e.g., Phytophthora sp. "niederhauserii" or Phytophthora sp. 2-04B. The decision whether or not to consider a group of isolates as a new species is arbitrary: new species cannot be distinguished solely based on a defined number of different nucleotides. A multilocus approach as used by Blair et al. (13) is useful for phylogenetic analysis, but not necessarily for species delimitations. Crucially, sequences should be consistently similar within species and distinct between species, thus pointing to reproductive isolation of the species (biological species concept). Host specificity and geographic isolation may well play an important role in this respect. A complicating factor with Phytophthora, however, is that the species that we know are often introduced pathogens and thus may only represent a single or a few clones of a species that is indigenous in other parts of the world. Such a single clonal lineage may therefore appear to be distinct from other species but if the overall intraspecific variation were known, it may well show significant overlap with character traits from existing species. In the pre-molecular era several species were presented in the literature as new species but, as a result of DNAbased identification, turned out to be synonymous to existing species. Examples of species that were listed as a distinct species in Erwin and Ribeiro (35) but were synonymized are $P$. arecae (synonym of $P$. palmivora), $P$. mexicana (synonym of $P$. capsici), and $P$. sinensis (synonym of $P$. melonis) $(35,82)$. We anticipate that the decrease in costs for (whole genome) sequencing, combined with intensified sampling will greatly support and accelerate species identification and delimitation in the genus Phytophthora in the coming years.

In biology, the value of proper and accurate species descriptions and a consistent nomenclature is obvious. Therefore the use of provisional names should be discouraged. In the Phytophthora literature many provisional names have been used without being formally described according to the International Code of Nomenclature for algae, fungi, and plants (the former International Code of Botanical Nomenclature). Since no type isolates have been assigned for these provisional species, it is not possible to verify whether or not newly collected isolates belong to a species with a provisional name. If these newly collected isolates are then described under a different name it may be difficult to link the provisional name to the later, validly published name.

\section{INTERSPECIFIC HYBRIDS}

There is increasing evidence that interspecific hybridization is not uncommon between Phytophthora species. Interspecific hybrids have been successfully created in the laboratory by sexual crossing of $P$. mirabilis with $P$. infestans $(40,68), P$. sojae with $P$. vignae (81), and $P$. capsici with $P$. tropicalis (29), or by fusion of zoospores of $P$. capsici and $P$. nicotianae (32). More importantly, naturally generated hybrids have also been found. Man in 't Veld et al. (77) described hybrids between $P$. cactorum and $P$. nicotianae occurring in greenhouses. Later hybrids between the same two species were found in Taiwan and Peru on loquat trees (56). Brasier et al. (17) described three variants of the new species P. alni; P. alni subsp. alni, $P$. alni subsp. uniformis, and $P$. alni subsp. multiformis. They were originally described as hybrids between $P$. cambivora and a species close to $P$. fragariae $(15,17)$ but according to Ioos et al. (58) these subspecies are a group of emergent heteroploid hybrids between two phylogenetically close Phytophthora species. A combination of nuclear and mitochondrial DNA analyses suggests that $P$. alni subsp. alni may have

\section{FIGURE 1}

Increase in the number of described Phytophthora species over time. The first species, $P$. infestans, was described in 1876.

By October 2011, the number of validly described and recognized species has risen

to 101. These taxa are listed in Tables 1 through 10. In this graph, lost species or species that cannot be cultured have been excluded.

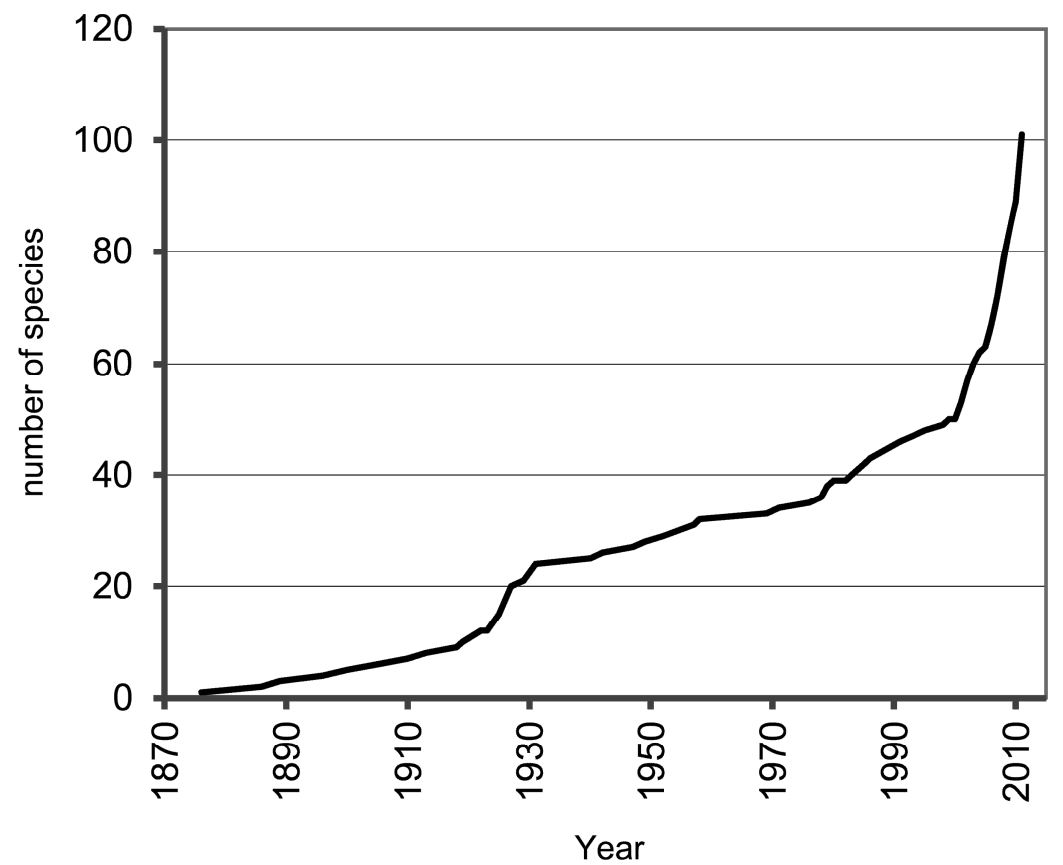

Vol. 102, No. 4, 2012 
been generated on several occasions by hybridization between $P$. alni subsp. uniformis and $P$. alni subsp. multiformis, or their respective ancestors. $P$. alni subsp. uniformis might have $P$. cambivora as a species ancestor, whereas $P$. alni subsp. multiformis seems to have been generated either by an ancient reticulation or by autopolyploidization (58). Interestingly, the hybrid variant $P$. alni subsp. alni seems far more destructive and aggressive on alder when compared with its parents. Evidence for altered host ranges and aggressiveness through hybridization has also been found in lab-induced hybrids (32). Another example is $P$. andina that has recently been shown to have emerged via hybridization of $P$. infestans and another unknown clade 1c hybrid Phytophthora parent (42).

The occurrence of hybridization in Phytophthora is important since hybridization may be responsible for rapid generation of new pathogens. Evidence for rapid evolution or genetic recombination in hybrids was presented by Man in 't Veld et al. (75). In the Netherlands they found several hybrid isolates derived from $P$. hedraiandra and $P$. cactorum which showed characteristics that may be explained by backcrossing between hybrids and parental species, or from further evolution. These interspecific hybrids appeared to be more virulent; in recent years they have been found far more often on Rhododendron than their parent species (75). Chamnanpunt et al. (21) observed high frequency mitotic gene conversion in intraspecific hybrids of $P$. sojae, resulting in heterokaryotic mycelium. This means that a single hybridization event may lead to a wide variety of genotypes through vegetative propagation by means of uninucleate zoospores.

Genetic (in-)stability and divergence in interspecific hybrids may play a major role in the rapid evolution of Phytophthora and its ability to explore new host plants. Epidemiological aspects of hybrids are comparable to those associated with the introduction of a new pathogen in a given environment. However, in contrast to new pathogens, which often represent a single genome of a single population (as in the case of $P$. ramorum for example), hybrids may well have increased genome plasticity.

Hardly anything is known about the way hybrids are generated in nature. One might speculate that the international plant trade and the current hydroponic culture system brings different, geographically isolated Phytophthora species close together, allowing hybrids to form by zoospore fusion (somatic hybrids) or through interspecific mating (sexual hybrids). A review in which these issues were addressed was published by Érsek and Nagy (33). Nirenberg et al. (87) described hybrids of $P$. cactorum and $P$. nicotianae pathogenic to cultivars of Pelargonium grandiflorum as a new (notho-)species, Phytophthora $\times$ pelgrandis, leaving other hybrids of these species unassigned. Assigning a species status to hybrids requires, in our opinion, a much better understanding of the formation mechanisms, the stability and the origin of hybrids. Also in this respect (whole genome) sequencing will be instrumental and should be exploited.

\section{LARGE-SCALE SURVEYS}

In the last decades, several plant-pathogenic Phytophthora species have caused huge damage to crops, landscape plants, forests, and ecosystems, for instance $P$. cinnamomi in Australia, $P$. alni in European forests and riparian vegetation, and P. ramorum in North America and Europe (19). The impact of Phytophthora diseases on plant species diversity in the affected ecosystems, or economic damage on wood stands, triggered several large-scale surveys to monitor the presence and diversity of Phytophthora populations $(9-11,14,20,59,60,65,85,101)$. In addition, isolates from earlier surveys were reexamined with modern identification techniques. These efforts not only increased our knowledge of host range of Phytophthora species or the habitats in which these species thrived, but also resulted in the discovery of a fair number of new Phytophthora species. For most of these species, a connection could be made between the presence of the species and disease symptoms on a nearby host. However, several new species were discovered that were distinct from all other prevailing Phytophthora species based on morphology and DNA sequence, but for which no apparent host plant was found $(9,62,85)$.

\section{PHYTOPHTHORA PHYLOGENIES BASED ON DNA SEQUENCES}

One of the first DNA regions to be used in phylogenetic analysis was the 5.8S ribosomal RNA gene and the flanking internal transcribed spacers 1 and 2 (ITS1 and ITS2) (70). The flanking genes of this region contain stretches of high homology that were used to design primers for polymerase chain reaction (PCR) amplification. For almost all Phytophthora species, the same primers can be used. The first extensive phylogenetic study of the genus Phytophthora based on ITS1 and ITS2 sequences was described by Cooke et al. (22). This study, which included 234 isolates from 50 distinct Phytophthora species, provided the basis for the clade nomenclature currently used to group Phytophthora species and replaced the Waterhouse classification which was found wanting and was never intended to reflect phylogenetic relationships in the first place.

The advantage of the ITS approach is that the sequence of ITS1, 5.8S, and ITS2 can be readily obtained and as a result the ITS sequences of a large number of Phytophthora species are currently available in GenBank. A disadvantage, however, is the low or in some cases even lack of variation in ITS sequences between closely related species raising doubts about the applicability of ITS regions for phylogenetic inference $(6,8)$. This led to a new approach for generating appropriate sequences for phylogenetic analysis of Phytophthora species. This approach involves the sequencing of "housekeeping" genes, i.e., genes, either mitochondrial or nuclear, encoding proteins with known functions in the metabolism of the organism. These genes also possess highly conserved regions that are suited for universal primer design, but the nucleotide variation within the genes is higher. This approach results in better resolved phylogenies when compared to ITSbased analyses (6). Introns often have a higher level of polymorphism when compared with exons and this higher level of polymorphism makes intron sequences more useful for phylogenetic studies. However, many Phytophthora genes lack introns and hence, larger stretches of exon sequences are needed to create a well-resolved phylogenetic tree.

The first significant example of a study using Phytophthora "housekeeping" genes was published by Martin and Tooley (78) who sequenced two mitochondrial genes, cytochrome oxidase I and II (cox 1 and $\operatorname{cox} 2$ ) from 51 isolates representing 27 Phytophthora species. However, it covered only a subset of the known Phytophthora species with clades that were less resolved when compared with the study by Cooke et al. (22) and the study used only mitochondrial genes, which are uniparentally inherited. As a result, the novel clade nomenclature that Martin and Tooley (78) introduced in their study for the genus Phytophthora did not prevail. In another study, the same authors (79) combined mitochondrial and ITS sequences. This study, however, was not aimed at resolving the overall Phytophthora phylogeny but at establishing the phylogenetic position of a few new Phytophthora species found in California in areas with sudden oak death.

In 2004, Kroon et al. (69) presented the first overall phylogenetic analysis of the genus based on sequences of multiple nuclear and mitochondrial genes. That study covered 113 isolates from 48 Phytophthora species and expanded on the firm basis of the clade nomenclature introduced by Cooke et al. (22). Separate analyses were carried out for both nuclear and mitochondrial regions, and for all regions combined. This revealed discrepancies 

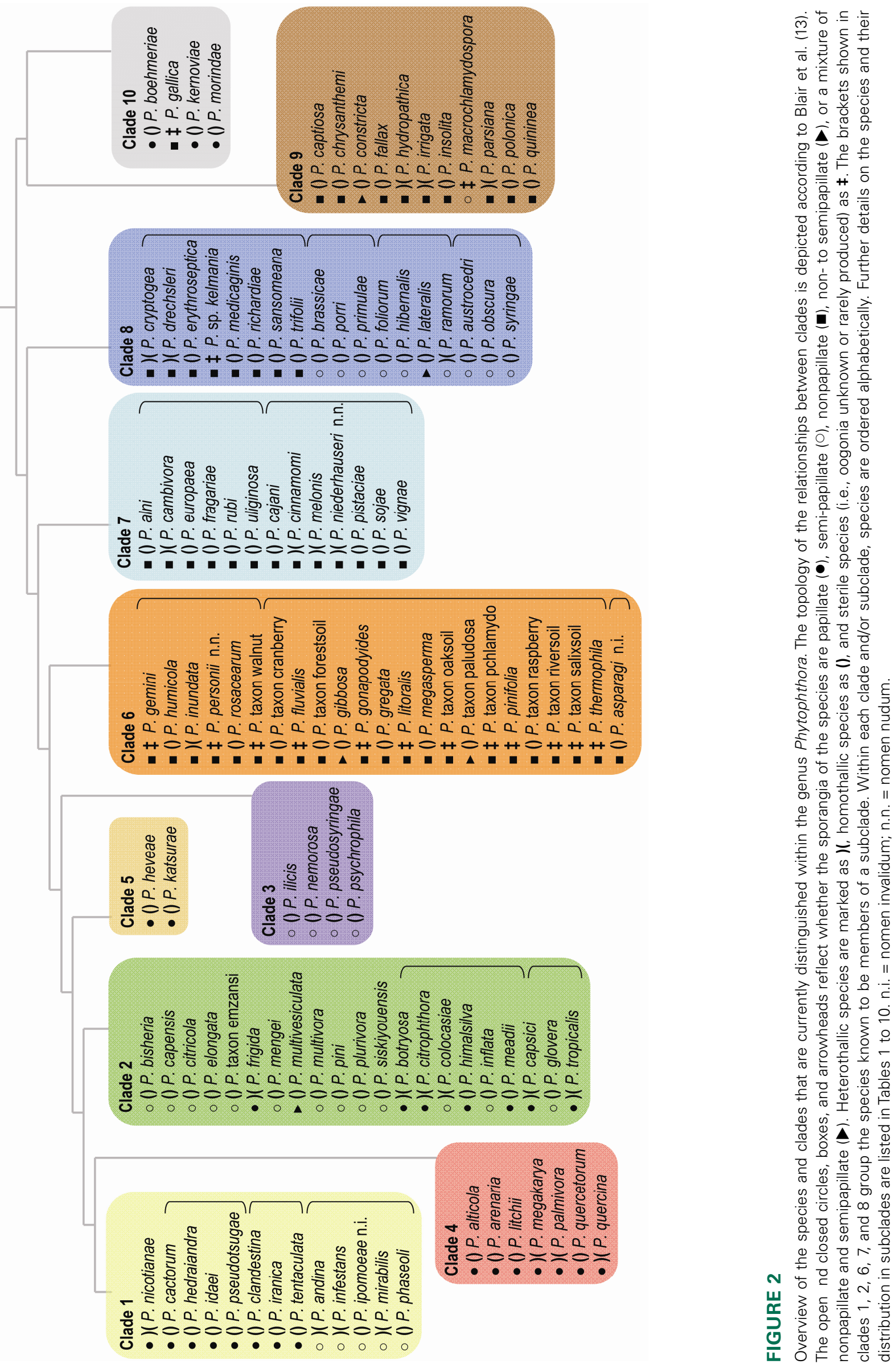
in the phylogenetic position of a number of Phytophthora isolates, hinting at interspecific mating or somatic hybridization events. Phenotypic traits from the Waterhouse key were interpolated on the phylogenetic tree, in order to speculate on the ancestry of traits like mating type, sporangium morphology and attachment of the antheridia to the oogonia. Four years later, Blair et al. (13) published an even more expanded multi-gene phylogeny based on seven nuclear genes, the sequences of which are available in the online Phytophthora database (90). For the analysis they included 8,700 nucleotides from seven loci in 234 isolates that represented 82 species, including many new Phytophthora species from recent surveys and this resulted in the most detailed and complete Phytophthora phylogeny available to date. That study as well as the online Phytophthora database (http://www.phytophthoradb.org/) (90) and the online Phytophthora identification tool (http://www.phytophthora-ID.org) (47) are extremely valuable resources for plant pathologists. Importantly, Blair et al. (13) defined the currently accepted clade and subclade structure.

\section{THE TEN CLADES IN THE GENUS PHYTOPHTHORA}

In this review we combined the data presented in the Phytophthora phylogeny by Blair et al. (13) with data on a large number of new Phytophthora species that have been described in the scientific literature since the release of the monograph in 1996 by Erwin and Ribeiro entitled 'Phytophthora diseases worldwide' (35). We consulted publications that appeared or were known to be in press before mid-October 2011. We give an overview of the 10 clades that are currently distinguished within the genus Phytophthora (Fig. 2). Some of the new species names have not been validly published. They are included with the species name followed by the abbreviation 'nom. nud.' or 'nom. inval.'; 'nom. nud.' (nomen nudum) is used when no description has been published (e.g., P. niederhauseri nom. nud.) and 'nom. inval.' (nomen invalidum) when the description is not valid because the type assignment or the Latin species description required prior to January 2012 was missing (e.g., P. asparagi nom. inval.). In the literature, the expression 'Phytophthora taxon host/substrate' or

TABLE 1

Clade 1 Phytophthora species

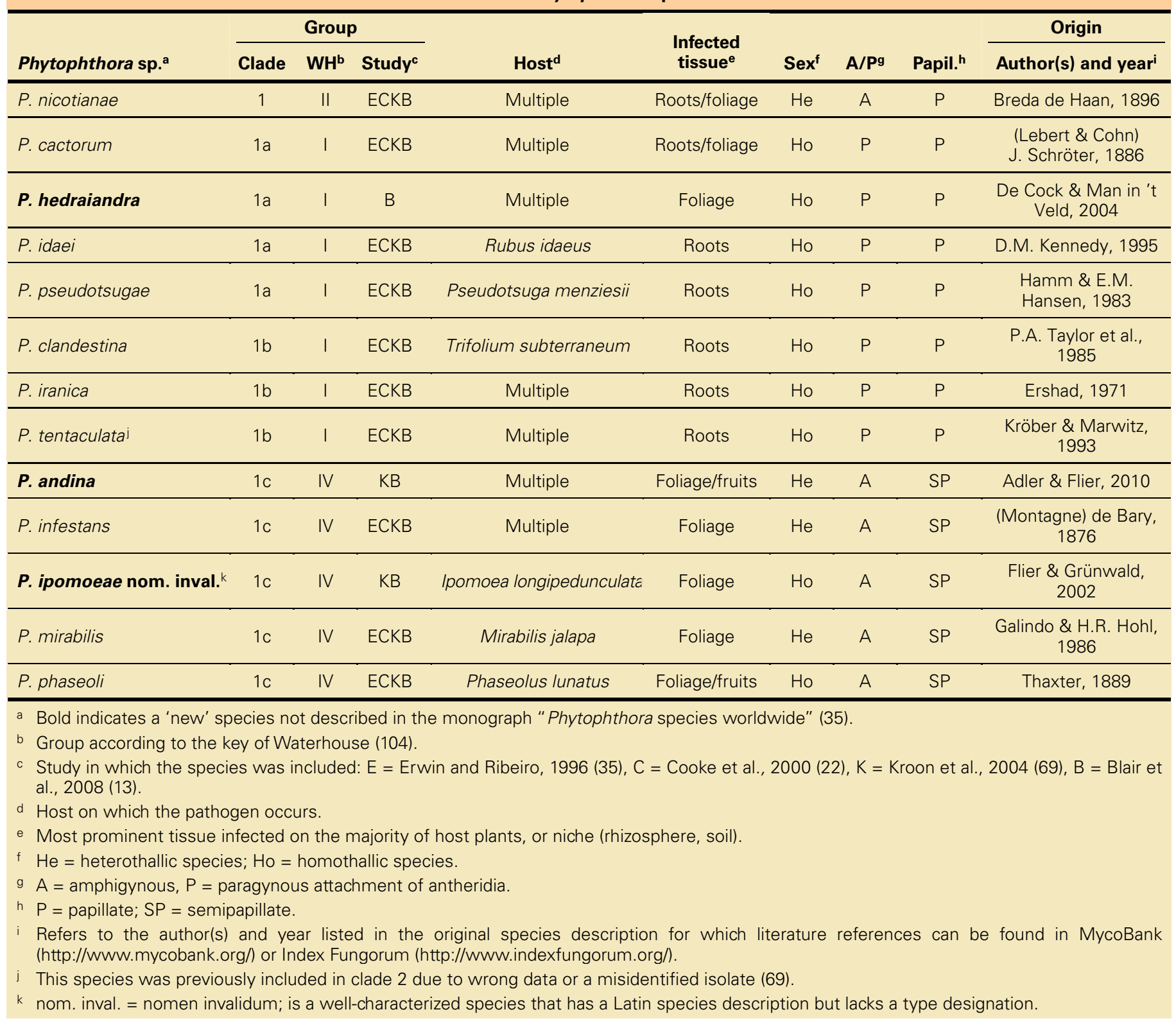


'Phytophthora sp. epithet' has been used to informally circumscribe phylogenetically distinct lineages that still need a formal description (e.g., $P$. taxon salixsoil). In this review we use the same expressions as in the literature. Per clade, the most notable characteristics for each new species are covered. The description is accompanied by a table listing all the species in the clade with the author(s) and year of publication as listed in the official species name database MycoBank (http://www.mycobank.org/) or Index Fungorum (http://www.indexfungorum.org/). In those databases the original literature references can be found. For species still lacking an official species description, the tables refer to the publication in which the name first appeared. These are marked with prefix 'Ref.' and included in the section with references (literature cited). For most species the Waterhouse groups are

TABLE 2

Clade 2 Phytophthora species

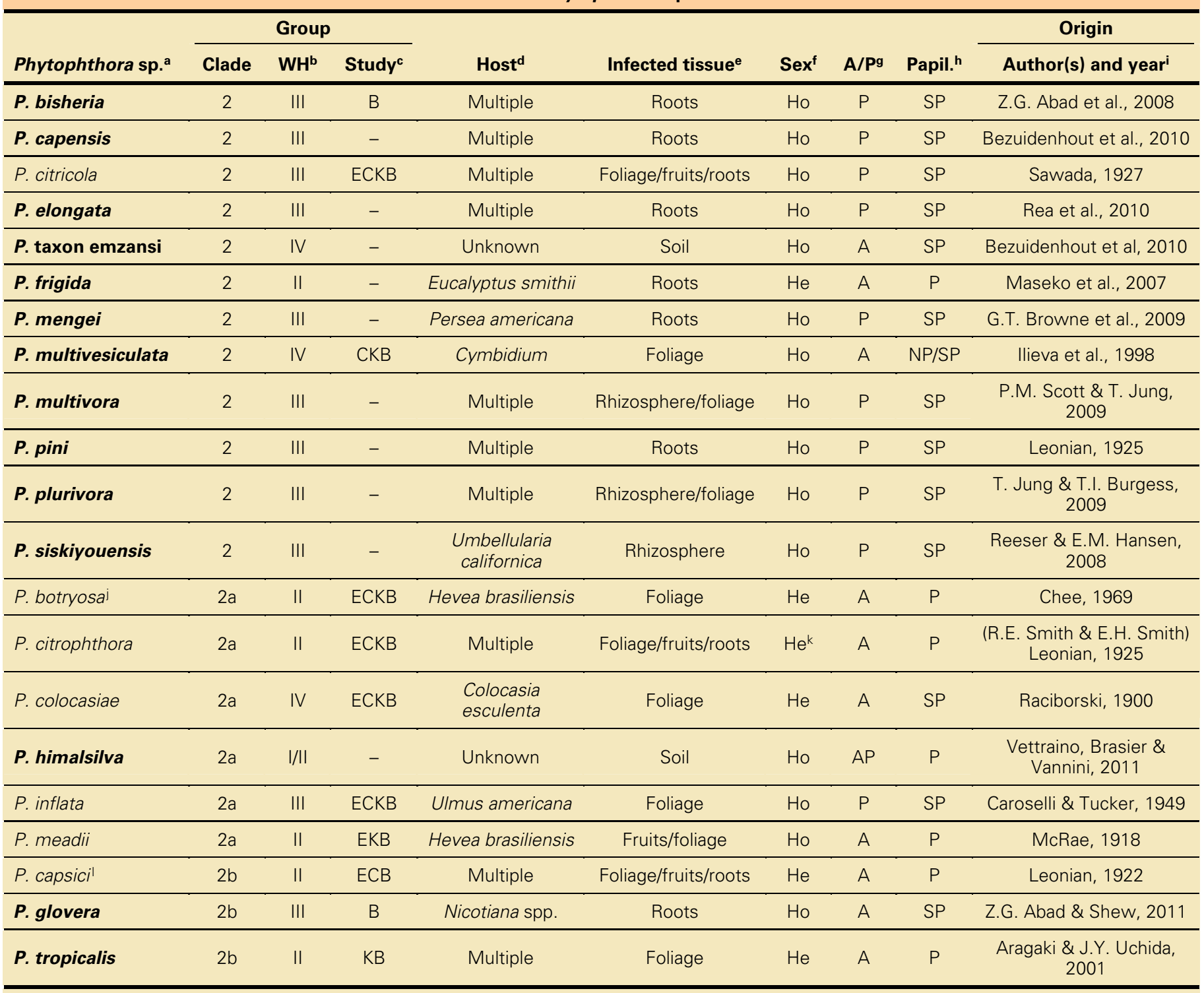

a Bold indicates a 'new' species not described in the monograph "Phytophthora species worldwide" (35).

b Group according to the key of Waterhouse (104).

c Study in which the species was included: E = Erwin and Ribeiro, 1996 (35), C = Cooke et al., 2000 (22), K = Kroon et al., 2004 (69), B = Blair et al., 2008 (13).

d Host on which the pathogen occurs.

e Most prominent tissue infected on the majority of host plants, or niche (rhizosphere, soil).

$f \mathrm{He}=$ heterothallic species; $\mathrm{Ho}=$ homothallic species.

g $\mathrm{A}=$ amphigynous, $\mathrm{P}=$ paragynous attachment of antheridia.

$\mathrm{P}=$ papillate; $\mathrm{SP}=$ semipapillate; $\mathrm{NP}=$ nonpapillate.

Refers to the author(s) and year listed in the original species description for which literature references can be found in MycoBank (http://www.mycobank.org/) or Index Fungorum (http://www.indexfungorum.org/)

j This species was previously included in clade 4 due to wrong data or a misidentified isolate (69).

$k$ There is ambiguity on the mating type of this species (35).

P. mexicana is a species described in Erwin and Ribeiro (35) that is synonymous to P. capsici (http://www.phytophthoradb.org/) and is not included in this table. 
included, linking the molecular data to phenotypic data. Also listed are their hosts, target tissues for infection, mating system, and morphology of sexual and asexual reproductive structures.

Clade 1. Clade 1 is a well-studied clade. It comprises 13 species including the most widely known species of Phytophthora, P. infestans (Table 1). Since 1996 (35) three new species have been added to this clade, one of which is $P$. andina in clade $1 \mathrm{c}$, a close relative of $P$. infestans and described recently by Oliva et al. (88). More recently, $P$. andina was shown to be a hybrid between $P$. infestans and an unknown clade $1 \mathrm{c}$ hybrid parent (42). Another new species that is a close associate of $P$. infestans is $P$. ipomoeae (37), which was found in the Toluca valley in central Mexico, a center of diversity of $P$. infestans and $P$. mirabilis (45). The third new species is $P$. hedraiandra, a pathogen that is provisionally positioned in clade 1a (25). Recently interspecific hybrids were found that seem to be the offspring of $P$. hedraiandra and $P$. cactorum (75), and P. nicotianae and P. cactorum (77). These hybrids can be confused with their parent species if only mitochondrial sequences are considered as these are uniparentally inherited.

Clade 1 contains Phytophthora species that are papillate or semipapillate, with only one type present in each subclade. For species in clades $1 \mathrm{a}$ and $1 \mathrm{~b}$, the zoosporangia are papillate, the attachment of antheridia to the oogonia is paragynous, and the pathogens mainly infect roots. Clade 1c species have amphigynous antheridia and semipapillate zoosporangia, which develop on distinctly differentiated sporangiophores. The sporangia are deciduous and spread by aerial dispersal. The species are foliar pathogens. $P$. nicotianae is singular in this clade; it could not be placed in one of the subclades of clade 1 based on sequence analysis, and it has amphigynous antheridia and papillate sporangia.

Clade 2. With the addition of 14 new species since 1996 (35), clade 2 has become one of the largest clades in the Phytophthora phylogeny with 21 species in total (Table 2). Isolates of five new clade 2 species, $P$. mengei, $P$. capensis, $P$. elongata, $P$. multivora, and $P$. plurivora, were previously considered as distinct subgroups within the $P$. citricola complex. One group of isolates was pathogenic on avocado trees, where they infected feeder roots and trunks. The pathogen responsible for this disease is now named $P$. mengei. It can be classified in clade 2 based on sequence homology with $P$. capsici and $P$. tropicalis, but its morphological traits place it just outside clade $2 \mathrm{~b}$ (52). P. multivora was found in the rhizosphere of declining Eucalyptus trees in Australia (99). In Europe, large-scale surveys for soilborne Phytophthora species were conducted in more than a thousand forests, nurseries, and seminatural stands showing devastating declines and diebacks of major forest tree species (60). Based on morphological and physiological characters and the similarity of ITS DNA sequences, the species causing the decline were routinely identified as $P$. citricola. In a more detailed characterization based on additional DNA sequence data, it was however concluded that the decline should be attributed to a new species that was named $P$. plurivora (60). P. capensis, a species from South Africa, has also recently been separated from $P$. citricola sensu stricto (12). The same study also describes isolates of a related new taxon provisionally named $P$. taxon emzansi, which has not yet been formally described as a new species. $P$. taxon emzansi can be distinguished from other members of the citricola complex by the production of amphigynous antheridia. $P$. pini was long considered to be a synonym of $P$. citricola but has recently been shown to be a valid species (53).

Another new species in clade 2, P. bisheria, causes root rot on strawberry in the United States, roses in The Netherlands, and raspberry in Australia (2). It is related to several other new species in this clade: the homothallic species $P$. multivesiculata (57) and $P$. elongata (95) and the heterothallic, papillate species $P$. frigida. This species is found on infected roots and collars of Eucalyptus trees in South Africa (80).

Soil and water stream monitoring experiments revealed the presence of a homothallic species in Oregon, P. siskiyouensis (96). Positioning in clade 2 was only based on ITS sequencing; additional sequence information should resolve its exact position in this clade. Another species, related to P. citrophthora, but with a homothallic instead of heterothallic mating system was found in Nepal. P. himalsilva was isolated from soil using baits; its host range is unknown (103). $P$. tropicalis is a species that is pathogenic on several hosts including Macadamia trees. Isolates of this species were initially described as $P$. capsici, but based on more detailed morphological analysis they were reclassified as $P$. tropicalis (7). In the early 1990s, a root rot disease of cultivated tobacco was observed in burley production areas in Brazil. The disease, called yellow stunt, is caused by the semipapillate, homothallic species $P$. glovera (4).

TABLE 3

Clade 3 Phytophthora species

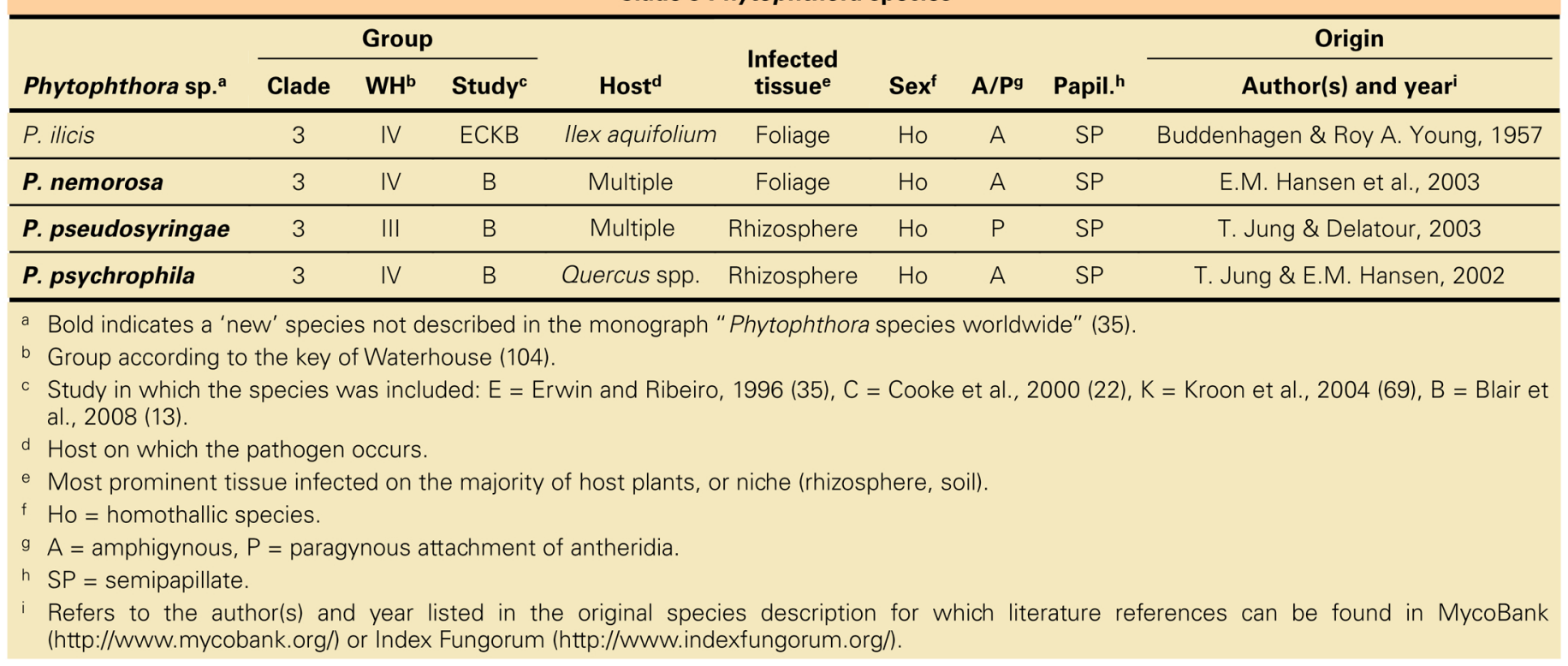


Species in clade 2 all have papillate or semipapillate zoosporangia, and the majority (15 out of 21 ) are homothallic.

Clade 3. Previously P. ilicis was the only species in clade 3 but in the last decade three new species have been added (Table 3). $P$. pseudosyringae was found in Europe in rhizosphere samples collected in declining oak stands and is associated with fine root and stem necrosis of beech (Fagus sylvatica) and alder (Alnus glutinosa) (64). P. pseudosyringae has also been found in the same regions and ecosystems in the United States as $P$. ramorum, together with another new species, $P$. nemorosa. P. nemorosa was isolated from myrtlewood and California bay laurel and causes lethal bole cankers on tanoak and coast live oak (49). P. psychrophila was isolated from rhizosphere samples from oak in Europe (Quercus robur) although no clear host could be found that was affected by this species (62).

All species in clade 3 have semipapillate sporangia, are homothallic, and are associated with trees.

Clade 4. Clade 4 is another small clade that expanded rapidly. The number of species has more than tripled compared to that in 1996 (35) (Table 4). During a large survey in the United States in 2004, isolates of the species $P$. quercetorum were frequently found with an oak leaf baiting method from soil samples (9). Although the pathogen has the ability to cause infection on oak, it has never been found to be associated with oak decline. A species that is responsible for oak decline is $P$. quercina, found on Quercus spp. throughout Europe (61). In South Africa, a new clade 4 species, $P$. alticola, was found on Eucalyptus trees, causing root and collar rot (80). Recently, Rea et al. (94) described $P$. arenaria, a new species associated with dieback of indigenous vegetation in Western Australia and pathogenic on Banksia species. Peronophythora litchii was formally transferred to Phytophthora by Göker et al. (39), based on multi-gene sequencing.

Species in clade 4 have papillate sporangia and are mainly pathogenic on roots. The homothallism/heterothallism distribution in this clade is about equal.

Clade 5. Clade 5 is the smallest distinct clade comprising only two species, $P$. heveae and $P$. katsurae (Table 5). These two species were already known in 1996 when Erwin and Ribeiro (35) published their inventory of the genus Phytophthora.

The two clade 5 species have papillate sporangia and are both homothallic with small amphigynous antheridia. P. katsurae is characterized by its distinctly ornamented oogonia.

Clade 6. This is another clade that has expanded enormously. Since 1996, 20 new or putative new species have been added resulting in a total of 23 divided over three subclades (Table 6). Clade 6 includes a lot of taxa that have not yet been formally described.

$P$. asparagi nom. inval. is a well characterized species but lacks a formal Latin diagnosis and type designation. It infects the spears and crown of asparagus plants and can cause significant damage in asparagus production areas (98). The same pathogen has also been isolated from infected agave plants in Australia (98). Another new species, $P$. taxon cranberry, is pathogenic on cranberry (92) and is closely related to $P$. gregata. $P$. rosacearum was previously classified as a subgroup of $P$. megasperma. Based on host range and ITS sequences, however, the group of isolates now forming the new species differed sufficiently to warrant a classification as a new species (50).

During large-scale surveys of dying vegetation in natural ecosystems and associated waterways in Western Australia many clade 6 isolates were found that could not be assigned to known species (20). This has by now resulted in the description of five

TABLE 4

Clade 4 Phytophthora species

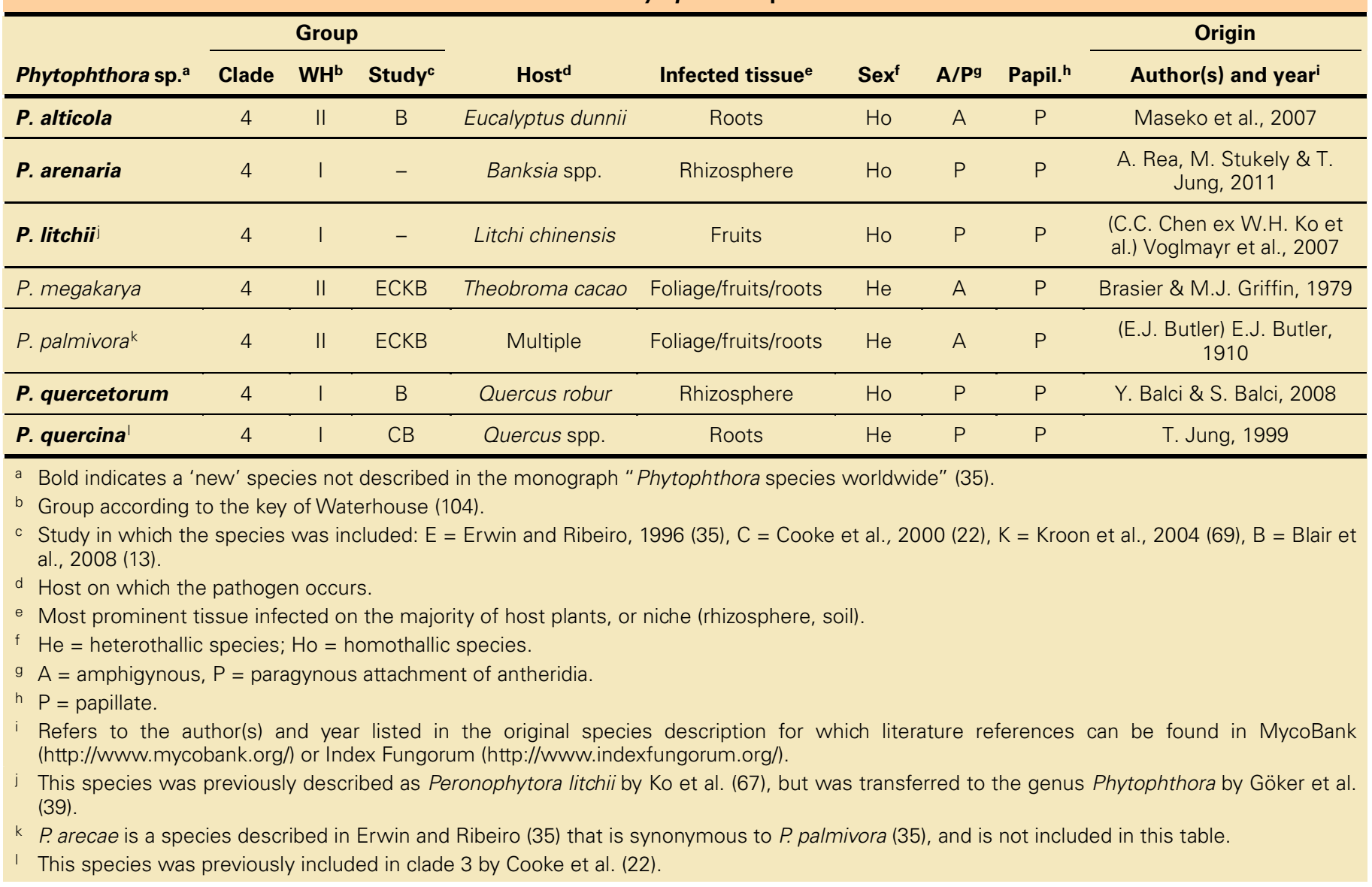


new clade 6 species, one described by Crous et al. (23) and four by Jung et al. (65) who also included an informally described clade 6 taxon. The latter, $P$. taxon paludosa, and two of the five new species, $P$. gregata and $P$. gibbosa, are homothallic (65). The other three, $P$. litoralis, $P$. thermophila, and $P$. fluvialis, are sexually sterile $(23,65)$. Some of $P$. litoralis isolates, though, could induce formation of gametangia in $P$. cinnamomi isolates and one of five tested isolates of $P$. thermophila produced oogonia when flooded with nonsterile soil extract (65). P. gibbosa can be easily distinguished from other clade 6 species by its ornamented oogonia. Also, its semi- to nonpapillate sporangia are rather unique for clade 6 species and so far shared only by $P$. taxon paludosa. All other clade 6 members produce nonpapillate sporangia.

In 2003, Brasier et al. (16) described a number of new clade 6 species that still await formal publication. These include $P$. taxon pgchlamydo, $P$. taxon oaksoil, $P$. taxon riversoil, $P$. taxon walnut, $P$. taxon raspberry, $P$. taxon forestsoil, and $P$. taxon salixsoil. The latter was also found by Nechwatal and Mengden (85) in the rhizosphere of reed stands (Phragmites australis) of Lake Constance, Germany. So far, no apparent disease symptoms have been found associated with $P$. taxon salixsoil but in disease assays it is pathogenic on leaves of Salix alba. Like many other clade 6 species, it is widely occurring in flooded habitats. Species of Phytophthora that are widely spread in ecosystems, but are not causing an apparent disease on available hosts may play a role in the breakdown of plant litter. It cannot be excluded, however, that they are pathogens of considerable significance (16).

Most species in clade 6 are infectious on roots or present in the rhizosphere. There are a few notable exceptions to this rule. In 2008, P. pinifolia was described as the cause of a new disease on pine trees in Chile $(30,31)$. Despite its placement in clade 6 it is a foliar pathogen that infects needles and shoots resulting in defoliation of trees in winter that can even lead to plant death. Another species found in an unexpected habitat is $P$. gemini; it was isolated from rotting Zostera marina leaves from saline water in the Netherlands (76). The same study also found several isolates of $P$. inundata in the same habitat. This clade 6 species was previously described on horse chestnut (Aesculus hippocastanum) and willow (Salix matsudana) in the UK and on flooded olive trees in Spain (18) but was not known to occur in salt water. Hardly anything is known about the occurrence of Phytophthora spp. in marine environments, mostly due to the lack of large scale surveys. A large number of unknown species may hide in this unexplored habitat.

All species in clade 6 have nonpapillate sporangia. Two species, however, produce not only nonpapillate but also semi- papillate sporangia. Over half of the species in this clade (12 out of 23) is sexually sterile or partially sterile, one species is clearly heterothallic, and the remaining 10 are homothallic.

Clade 7. Clade 7 comprises 13 species of which six have first been described after 1996 (35). One of the new species is $P$. alni, the causal agent of a destructive disease on alder that first emerged in the UK in 1993 and in subsequent years was found to be widely spread in Europe (17). As described above in the section on hybrids, $P$. alni is a species hybrid complex with three known subspecies. Two other new clade 7 species found in central Europe are P. europaea and P. uliginosa (62). Both were present in the rhizosphere of oak (Quercus robur), but only P. uliginosa appears to be a true pathogen on oak. The group of isolates known as the $P$. megasperma complex houses a number of putative new species that can be distinguished based on sequence analysis. One of these is a new clade 7 species named $P$. pistaciae that is found on pistachio trees (82) (Table 7).

For $P$. fragariae Erwin and Ribeiro (35) listed three varieties, var. fragariae, var. rubi, and var. oryzobladis. Man in 't Veld (73) provided evidence that strains isolated from strawberry (Fragaria $\times$ ananassa) are distinct from strains isolated from raspberry (Rubus idaeus). The two pathogenic varieties var. fragariae and var. rubi are reproductively isolated and hence $P$. fragariae var. $r u b i$ was raised to the species level and renamed $P$. rubi. Based on morphological characteristics Ho (51) proposed to also raise $P$. fragariae var. oryzobladis to the species level. The isolates, however, could not be cultured and the species was not maintained in any culture collection. Hence, we consider $P$. oryzo-bladis as a lost species.

All species in clade 7 are nonpapillate and mostly pathogenic on roots. There is a random distribution of homothallism and heterothallism in clade $7 \mathrm{~b}$ while in clade $7 \mathrm{a}$ homothallism is more pronounced.

Clade 8. At present, clade 8 approaches the number of species in clades 2 and 6, making these three the largest clades in the Phytophthora phylogeny (Table 8). Since 1996 (35) seven species have been added.

Isolates that are now classified as $P$. sansomeana were previously grouped in the $P$. megasperma complex (50). All the isolates in the $P$. megasperma complex shared morphological traits, but other characteristics, like host range and optimal growth temperature, differed significantly. $P$. sansomeana was isolated from infected soybean plots. Soybean crops with resistance or tolerance to $P$. sojae suffered great damage from this new disease and the pathogen isolated from infected plants differed from $P$. sojae based on sequence analyses. Man in 't Veld et al. (74) used

TABLE 5

Clade 5 Phytophthora species

\begin{tabular}{|c|c|c|c|c|c|c|c|c|c|}
\hline \multirow[b]{2}{*}{ Phytophthora sp. } & \multicolumn{3}{|c|}{ Group } & \multirow[b]{2}{*}{ Host $^{c}$} & \multirow{2}{*}{$\begin{array}{l}\text { Infected } \\
\text { tissue }^{d}\end{array}$} & \multirow[b]{2}{*}{ Sex } & \multirow[b]{2}{*}{$A / P^{f}$} & \multirow[b]{2}{*}{ Papil.g } & \multirow{2}{*}{$\frac{\text { Origin }}{\text { Author(s) and yearh }}$} \\
\hline & Clade & $\mathbf{W H}^{\mathbf{a}}$ & Studyb & & & & & & \\
\hline P. heveae & 5 & II & ECKB & Multiple & Fruits/roots & Ho & $A$ & $P$ & A.W. Thompson, 1929 \\
\hline P. katsurae & 5 & II & ECKB & Castanea crenata & Trunk & Ho & A & $P$ & W.H. Ko \& H.S. Chang, 1979 \\
\hline $\begin{array}{l}\text { a Group according } \\
\text { b Study in which th } \\
\text { al., } 2008 \text { (13). } \\
\text { c Host on which th } \\
\text { d Most prominent t } \\
\text { e Ho = homothallic } \\
\text { f } \mathrm{A}=\text { amphigynous } \\
\text { g } \mathrm{P}=\text { papillate. } \\
\text { h Refers to the at } \\
\text { (http://www.myco }\end{array}$ & $\begin{array}{l}\text { the key } \\
\text { species } \\
\text { pathoge } \\
\text { ssue infe } \\
\text { species. } \\
\text { attachme } \\
\text { thor(s) ar } \\
\text { oank.org/ }\end{array}$ & $\begin{array}{l}\text { of Wate } \\
\text { was inc } \\
\text { noccur } \\
\text { cted on } \\
\text { nt of an } \\
\text { hd year }\end{array}$ & $\begin{array}{l}\text { erhouse (1 } \\
\text { sluded: } E= \\
\text { s. } \\
\text { the major } \\
\text { theridia. } \\
\text { listed in }\end{array}$ & $\begin{array}{l}\text { Erwin and Ribeiro, } \\
\text { ty of host plants, or }\end{array}$ & $\begin{array}{l}1996 \text { (35), C = } \\
\text { niche (rhizosp }\end{array}$ & re, soil) & 2000 & (22), $K=K$ & oon et al., 2004 (69), B = Blair et \\
\hline
\end{tabular}


isozyme analysis and ITS sequence data to show that a group of isolates placed in the species $P$. porri in clade $8 \mathrm{~b}$, in fact represent a different species. This pathogen was named $P$. brassicae; it infects roots and collars of cabbage and can cause massive postharvest damage (74).

With the identification of a new species that is closely related to $P$. syringae, Grünwald et al. (48) recently revisited the subclade structure in this clade. Based on phylogenetic analyses of eight nuclear genes and one mitochondrial gene, they provided significant support for the introduction of a fourth subclade, $8 \mathrm{~d}$, that comprises two new species in addition to $P$. syringae. P. austrocedri, which was described incorrectly as $P$. austrocedrae (and should be corrected according to Art. 32.7 of the International Code of Botanical Nomenclature), causes damage on the conifer

TABLE 6

Clade 6 Phytophthora species

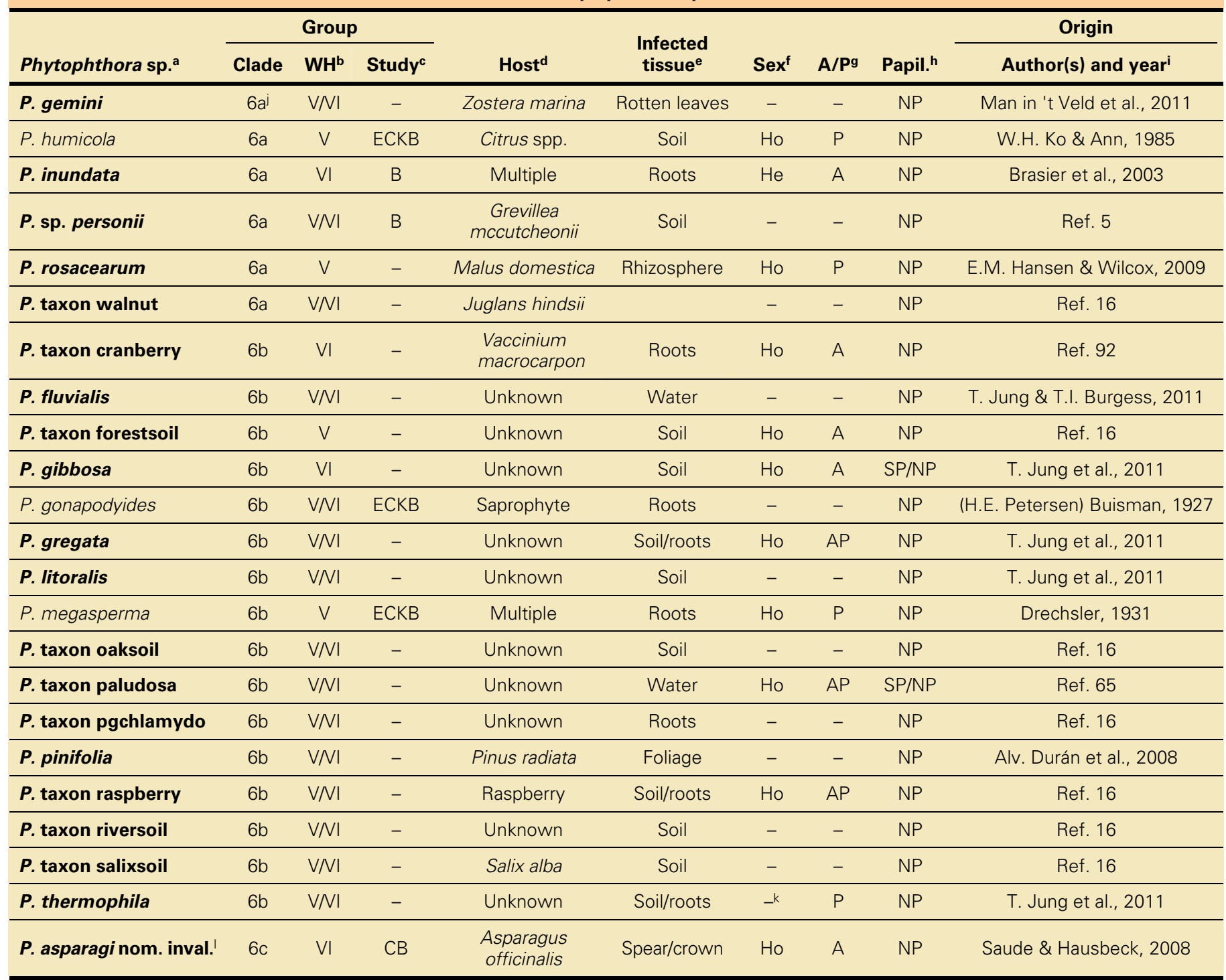

a Bold indicates a 'new' species not described in the monograph "Phytophthora species worldwide" (35).

b Group according to the key of Waterhouse (104).

c Study in which the species was included: E = Erwin and Ribeiro, 1996 (35), C = Cooke et al., 2000 (22), K = Kroon et al., 2004 (69), B = Blair et al., 2008 (13).

d Host on which the pathogen occurs.

e Most prominent tissue infected on the majority of host plants, or niche (rhizosphere, soil).

$f \mathrm{He}=$ heterothallic species; $\mathrm{Ho}=$ homothallic species; $-=$ oogonia unknown or rarely produced

g $A=$ amphigynous, $P=$ paragynous attachment of antheridia; - = unknown.

h $\mathrm{SP}=$ semipapillate; NP = nonpapillate.

Refers to the author(s) and year listed in the original species description for which literature references can be found in MycoBank (http://www.mycobank.org/) or Index Fungorum (http://www.indexfungorum.org/). For species still lacking an official species description, the publication in which the name first appeared is given, marked with prefix 'Ref.' and followed by the reference number.

i For consistency among clades the subclades have the lower case letters a, b, and c, instead of the Roman numbers I, II and III, as in Brasier et al. (16) and Jung et al. (65).

k One of five isolates tested produced oogonia when flooded with non sterile soil filtrate (65).

I nom. inval. = nomen invalidum; is a well characterized species but lacks a formal Latin diagnosis and type designation. 
Austrocedrus chilensis in Patagonia (44). P. obscura was detected in the United States infecting foliage of Kalmia latifolia and in Germany in soil samples (48).

The most notorious new species in clade 8 is $P$. ramorum, the causal agent of sudden oak death (SOD), responsible for widespread mortality of oaks in the United States $(97,105)$. Infections in Europe seemed to be mainly limited to Rhododendron and Viburnum. Recently, however, it was found to cause widespread defoliation and dieback of Japanese larch (Larix kaempferi) in the UK (19). Since the late 1990s, it has had major impact on ecosystems in the United States. During the SOD surveys in the United States, a new pathogen of Azalea was found that was sufficiently different to define it as a new species, $P$. foliorum (28).

All species in clade $8 \mathrm{a}$ are nonpapillate and those in clade $8 \mathrm{~b}$, $8 \mathrm{c}$, and $8 \mathrm{~d}$ are semipapillate. The one exception is P. lateralis, which was typed as nonpapillate in the original description by Tucker and Milbrath (cited in 35). However, recent examination of several isolates, including the type isolate, indicated that $P$. lateralis isolates produce both nonpapillate and semipapillate sporangia (106, A. W. A. M. de Cock, personal communication). The majority of the clade 8 species (15 out of 18) are homothallic.

Clade 9. Clade 9 was one of the less-resolved clades in the phylogeny published by Kroon et al. (69) but has expanded enormously since 1996 (35) (Table 9).

One of the new species is $P$. parsiana, a pathogen of pistachio, almond, and fig (83). Isolates described as $P$. parsiana formed a heterogeneous group and should be considered a species complex. Recently, a group of distinct isolates belonging to this complex was described as the new species named $P$. hydropathica by Hong et al. (55). It was recovered from necrotic leaves and blighted shoots of Rhododendron and Kalmia. Another related species, $P$. chrysanthemi, was isolated from Chrysanthemum. It can be distinguished from $P$. parsiana by its homothallic mating behavior and paragynous antheridia (84).

$P$. irrigata was isolated from irrigation reservoirs and natural waterways (54). It was found to be pathogenic on Azalea. P. polonica was isolated from the rhizosphere of infected alder trees in Poland. Belbahri et al. (11) placed the species in clade 8c sensu Kroon (69), but in the phylogeny by Blair et al. (13) that has a

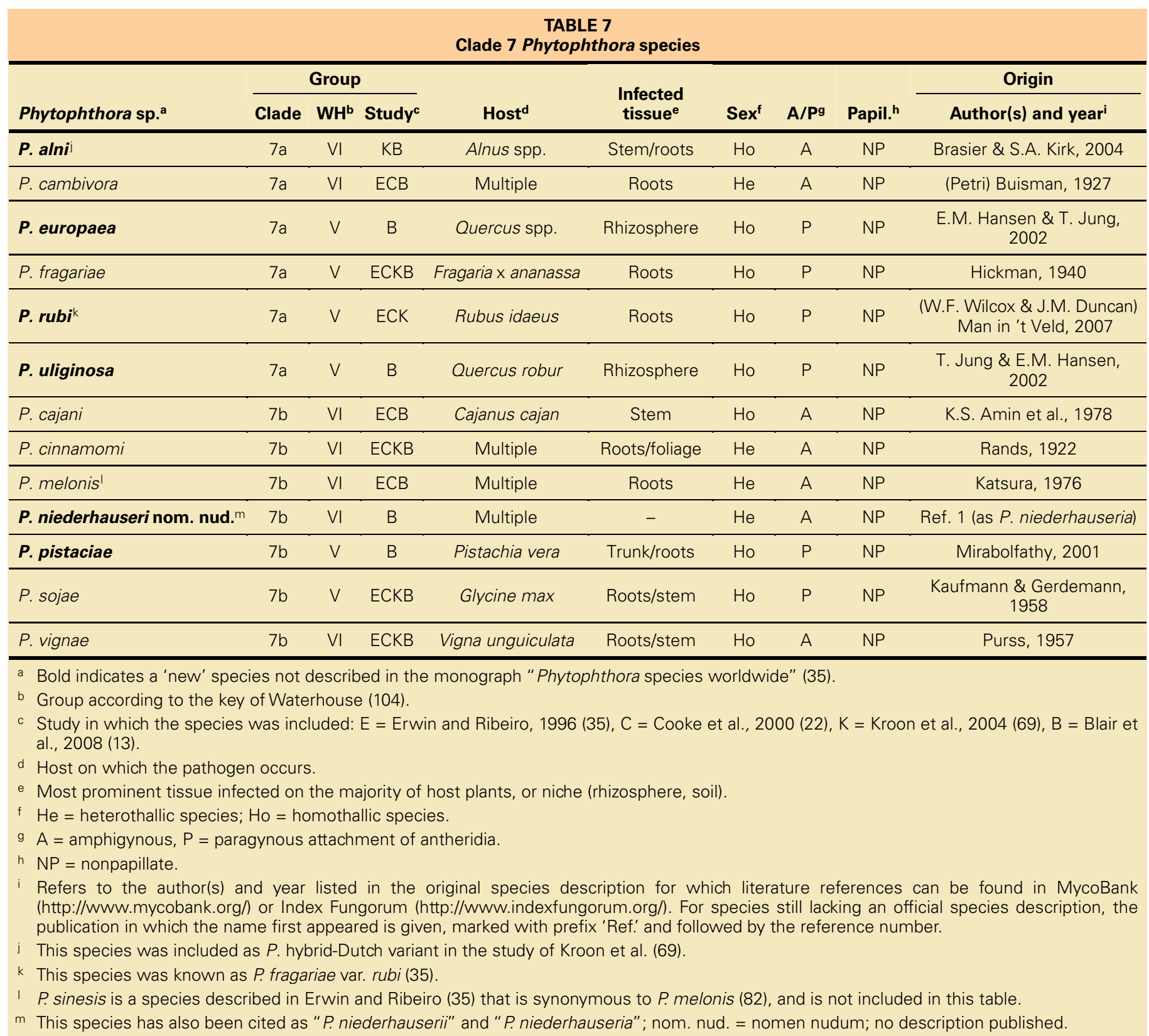


better resolution, $P$. polonica could be assigned to clade 9 . Several new pathogens of Eucalyptus trees have been described in recent years. Two of these, $P$. captiosa and $P$. fallax that are associated with a crown disease in Eucalyptus plantations in New Zealand, were also added as new species to clade 9 (26). P. constricta is another new species found in association with dieback of indigenous vegetation in Western Australia, together with the clade 4 species $P$. arenaria. Similar to $P$. arenaria, $P$. constricta was found to be pathogenic on Banksia species (94).

Species in clade 9 are nonpapillate (except for $P$. macrochlamydospora) and mainly found in the soil. Most species in this clade are homothallic.

Clade 10. Like clade 3, clade 10 was previously represented by only one species and now comprises four (Table 10). One new species is $P$. gallica (63), which was isolated from soil and responsible for a decline in stands of oak and reed in Germany and France. Another recently described species in clade 10 is $P$. kernoviae, a pathogen of beech found in Cornwall in the UK (14). The third new species is $P$. morindae, which caused a severe foliar blight and fruit rot disease of noni (Morinda citrifolia L. var. citrifolia) on the island of Hawaii in 1999 (86).

Species in clade 10 are papillate and pathogenic on foliage and stem with the exception of $P$. gallica. New phylogenetic analyses on the complete set of Phytophthora species may shift $P$. gallica from clade 10 to clade 9.

Lost species. In the reference work of Erwin and Ribeiro (35), nine species are described that are not included in Tables 1 to 10 in this review or in Figure 1. They were also not included in the

\begin{tabular}{|c|c|c|c|c|c|c|c|c|c|}
\hline \multicolumn{10}{|c|}{$\begin{array}{c}\text { TABLE } 8 \\
\text { Clade } 8 \text { Phytophthora species }\end{array}$} \\
\hline Phytophthora sp. ${ }^{a}$ & \multicolumn{3}{|c|}{ Group } & Host $^{d}$ & $\begin{array}{l}\text { Infected } \\
\text { tissue }\end{array}$ & Sex & $\mathrm{A} / \mathrm{Pg}^{\mathrm{g}}$ & Papil. $^{h}$ & $\frac{\text { Origin }}{\text { Author(s) and yeari }}$ \\
\hline P. cryptogea & $8 a$ & $\mathrm{VI}$ & ECKB & Multiple & Roots/foliage & $\mathrm{He}$ & A & NP & Pethybridge \& Lafferty, 1919 \\
\hline P. drechsleri & $8 a$ & $\mathrm{VI}$ & ECKB & Multiple & Roots & $\mathrm{He}$ & A & NP & Tucker, 1931 \\
\hline P. sp. kelmania & $8 a$ & $\mathrm{VNI}$ & B & Gerbera spp. & - & - & - & NP & Ref. 3 \\
\hline P. medicaginis & $8 a$ & V & ECB & Medicago sativa & Roots & Ho & PA & NP & $\begin{array}{l}\text { E.M. Hansen \& D.P. Maxwell, } \\
1991\end{array}$ \\
\hline P. richardiae & $8 a$ & $\mathrm{VI}$ & ECKB & $\begin{array}{l}\text { Zantedeschia } \\
\text { aethiopica }\end{array}$ & Roots & Ho & A & NP & Buisman, 1927 \\
\hline P. brassicae & $8 b$ & IV & KB & Brassica oleracea & Head (storage) & Ho & A & SP & De Cock \& Man in 't Veld, 2002 \\
\hline P. porri & $8 b$ & III & ECB & Allium porrum & Foliage & Ho & PA & SP & Foister, 1931 \\
\hline P. primulae & $8 b$ & III & ECB & Primula spp. & Roots & Ho & PA & SP & J.A. Tomlinson, 1952 \\
\hline P. foliorum & $8 c$ & III & B & Azalea spp. & Foliage & Ho & PA & SP & Donahoo \& Lamour, 2006 \\
\hline P. hibernalis & $8 c$ & IV & EKB & Multiple & Foliage/fruits & Ho & A & SP & Carne, 1925 \\
\hline P. lateralis & $8 c$ & V & ECKB & $\begin{array}{l}\text { Chamaecyparis } \\
\text { lawsoniana }\end{array}$ & Roots & Ho & $P$ & SP/NP & Tucker \& Milbrath, 1942 \\
\hline P. ramorum & $8 c$ & IV & $\mathrm{KB}$ & Multiple & Trunk/foliage & $\mathrm{He}$ & A & SP & Werres et al., 2001 \\
\hline \multicolumn{10}{|c|}{$\begin{array}{l}\text { b Group according to the key of Waterhouse (104). } \\
\text { c Study in which the species was included: E = Erwin and Ribeiro, } 1996 \text { (35), C = Cooke et al., } 2000 \text { (22), K= Kroon et al., } 2004 \text { (69), B = Blair et } \\
\text { al., } 2008 \text { (13). }\end{array}$} \\
\hline \multicolumn{10}{|c|}{ d Host on which the pathogen occurs. } \\
\hline \multicolumn{10}{|c|}{ e Most prominent tissue infected on the majority of host plants, or niche (rhizosphere, soil). } \\
\hline \multicolumn{10}{|c|}{$f \mathrm{He}=$ heterothallic species; $\mathrm{Ho}=$ homothallic species; $-=$ oogonia unknown or rarely produced. } \\
\hline \multicolumn{10}{|c|}{ g $\mathrm{A}=$ amphigynous, $\mathrm{P}=$ paragynous attachment of antheridia; $-=$ unknown. } \\
\hline \multicolumn{10}{|c|}{ h SP = semipapillate; NP = nonpapillate. } \\
\hline \multicolumn{10}{|c|}{$\begin{array}{l}\text { Refers to the author(s) and year listed in the original species description for which literature references can be found in MycoBank } \\
\text { (http://www.mycobank.org// or Index Fungorum (http://www.indexfungorum.org//. For species still lacking an official species description, the } \\
\text { publication in which the name first appeared is given, marked with prefix 'Ref.' and followed by the reference number. }\end{array}$} \\
\hline \multicolumn{10}{|c|}{ This species was previously included in clade 10 by Cooke et al. (22). } \\
\hline k Improper Latin tern & & & & & & & & & \\
\hline
\end{tabular}


TABLE 9

Clade 9 Phytophthora species

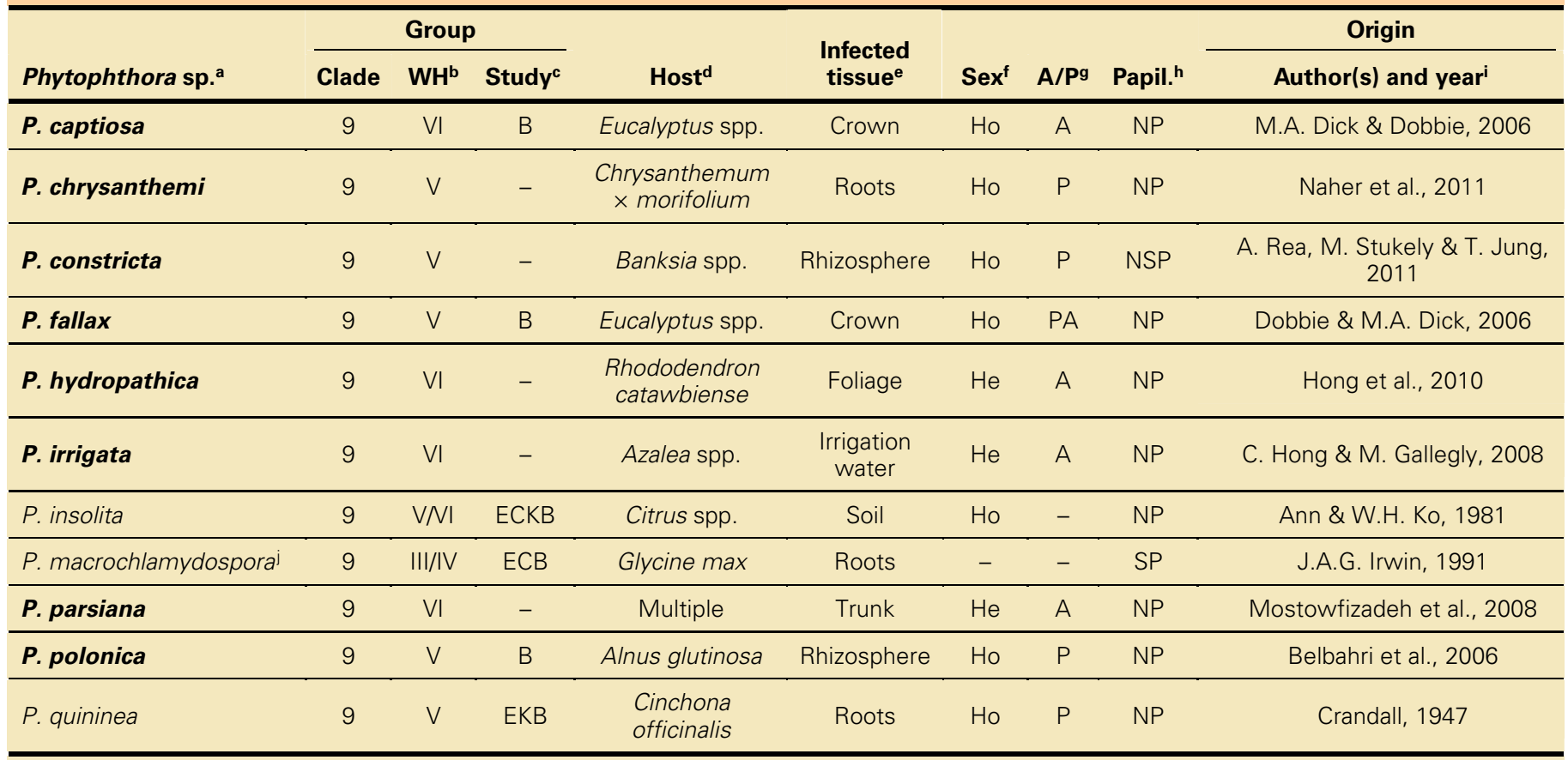

a Bold indicates a 'new' species not described in the monograph "Phytophthora species worldwide" (35).

b Group according to the key of Waterhouse (104).

c Study in which the species was included: $E=$ Erwin and Ribeiro, 1996 (35), C = Cooke et al., 2000 (22), K = Kroon et al., 2004 (69), B = Blair et al., 2008 (13).

d Host on which the pathogen occurs.

e Most prominent tissue infected on the majority of host plants, or niche (rhizosphere, soil).

$f \mathrm{He}=$ heterothallic species; $\mathrm{Ho}=$ homothallic species; $-=$ oogonia unknown or rarely produced.

g $A=$ amphigynous, $P=$ paragynous attachment of antheridia; - = unknown.

h $\mathrm{SP}=$ semipapillate; NP = nonpapillate; NSP non- to semipapillate.

Refers to the author(s) and year listed in the original species description for which literature references can be found in MycoBank (http://www.mycobank.org/) or Index Fungorum (http://www.indexfungorum.org/).

This species was previously included in clade 10 by Cooke et al. (22)

\section{TABLE 10}

Clade 10 Phytophthora species

\begin{tabular}{|c|c|c|c|c|c|c|c|c|c|}
\hline \multirow[b]{2}{*}{ Phytophthora sp. ${ }^{\text {a }}$} & \multicolumn{3}{|c|}{ Group } & \multirow[b]{2}{*}{ Host $^{\text {d }}$} & \multirow{2}{*}{$\begin{array}{l}\text { Infected } \\
\text { tissue }^{\mathrm{e}}\end{array}$} & \multirow[b]{2}{*}{ Sex } & \multirow[b]{2}{*}{$\mathrm{A} / \mathrm{Pg}^{\mathrm{g}}$} & \multirow[b]{2}{*}{ Papil. $^{h}$} & \multirow{2}{*}{$\begin{array}{c}\text { Origin } \\
\text { Author(s) and year }\end{array}$} \\
\hline & Clade & $\mathbf{W H}^{\mathbf{b}}$ & Study ${ }^{c}$ & & & & & & \\
\hline P. boehmeriae & 10 & ॥ & EKB & Multiple & Foliage & Ho & A & $P$ & Sawada, 1927 \\
\hline P. gallica & 10 & VNI & - & Quercus robur & Rhizosphere & - & - & NP & T. Jung \& J. Nechwatal, 2008 \\
\hline P. kernoviae & 10 & II & B & Multiple & Stem/foliage & Ho & A & $P$ & Brasier, Beales \& S.A. Kirk, 2005 \\
\hline P. morindae & 10 & II & - & Morinda citrifolia & Foliage/fruit & $\mathrm{Ho}$ & $A$ & $P$ & Z.G. Abad \& S.C. Nelson, 2010 \\
\hline
\end{tabular}

a Bold indicates a 'new' species not described in the monograph "Phytophthora species worldwide" (35).

b Group according to the key of Waterhouse (104).

c Study in which the species was included: E = Erwin and Ribeiro, 1996 (35), C = Cooke et al., 2000 (22), K = Kroon et al., 2004 (69), B = Blair et al., 2008 (13).

d Host on which the pathogen occurs.

e Most prominent tissue infected on the majority of host plants, or niche (rhizosphere, soil).

f $\mathrm{Ho}=$ homothallic species; $-=$ oogonia unknown or rarely produced.

g $A=$ amphigynous attachment of antheridia; - = unknown.

h $\mathrm{P}=$ papillate; $\mathrm{NP}=$ nonpapillate.

i Refers to the author(s) and year listed in the original species description for which literature references can be found in MycoBank (http://www.mycobank.org/) or Index Fungorum (http://www.indexfungorum.org/). 
phylogenies presented by Kroon et al. (69) and Blair et al. (13). The isolates on which these species descriptions are based were no longer available either because they could not be properly cultured or were not properly stored for long term preservation. Since no sequence data are available for these species, they can never be inincluded in the current phylogenies. It is even possible that new isolates from these "lost" species have been put forward as new species. For many new species the Waterhouse criteria were included in the description but a comparison to check if such a new species coincides with another previously described "lost" species is usually lacking. Since the Waterhouse grouping largely coincides with particular clades or subclades, and species within a (sub)clade share habitat or host type, it should be feasible to deduce the position of "lost" species in the Phytophthora phylogeny and here we made an attempt to do so. Over the years several species have been described in the literature that were lost afterwards; this section, however, is limited to the nine "lost" species that were included in the Erwin and Ribeiro monograph (35).

$P$. cyperi and $P$. cyperi-bulbosi are semipapillate species that are pathogenic on Cyperus spp. and may belong in clade 2, 3, 8b, or 8c. However, the latter species has thick-walled, verrucose oogonium walls and could not be cultivated; it could also belong to the Sclerosporales.

$P$. eriugena causes necrosis on leaves and stems of Cypres (Chamaecyparis lawsoniana) and although it has papillate sporangia, it was placed in Waterhouse group IV. This exceptional status makes it hard to find a suitable clade for this species.

$P$. fragariae var. oryzobladis is a pathogen on rice. Ho (51) observed that this variety differs significantly from $P$. fragariae and suggested to name it $P$. oryzo-bladis. Unlike $P$. fragariae it produces only amphigynous antheridia and the oogonia are shaped differently. With its nonpapillate sporangia it may still fall in clade 7 like $P$. fragariae, but could also belong to clade 6,8 , or 9 .

$P$. italica is a root pathogen of myrtle (Myrtus communis) in Italy. Since it has papillate sporangia and is a root pathogen, it could fall in clade $1,2,4,5$, or 10 , which all contain papillate species. Of these only clade 1 and clade 4 contain species with paragynous antheridia. Since $P$. italica has strictly paragynous antheridia and is very similar to $P$. iranica, it likely belongs to clade 1.

$P$. japonica is pathogenic on rice (Oryza sativa) and has nonpapillate sporangia. It could belong in either clade $6,7,8$, or 9 .

P. lepironiae is a pathogen of the reed Lepironia mucronata that most likely belongs to clade $2,3,8 \mathrm{~b}$, or $8 \mathrm{c}$.

$P$. undulata is a peculiar species. The species was originally described as Pythium undulatum (91) but transferred to Phytophthora by Dick (27). Several sequences are available in GenBank and some indeed cluster with sequences from Phytophthora species and some with Pythium sequences. According to the phylogenetic study of Lévesque and De Cock (72), this species clearly belongs in the genus Pythium and should be referred to as Pythium undulatum. To clarify this discrepancy the morphological characteristics of isolates of which the sequences cluster with Phytophthora species should be reanalysed.

$P$. verrucosa was described as a pathogen causing foot rot on tomato and having nonpapillate sporangia. It could be a member of clade $8 \mathrm{a}$, which consists of other species that are pathogenic on roots of solanaceous host, are nonpapillate, and have both paragynous and amphigynous antheridia. However, the very thick, predominantly verrucose oogonium wall and the fact that the species could not be cultured suggest that it does not belong to Phytophthora. It might well belong to the Sclerosporales.

\section{CONCLUSION}

Plant diseases caused by Phytophthora species will remain an ever increasing threat to agriculture and natural ecosystems. This overview includes 116 species, 15 of which await valid publication, but for sure, this is an underrepresentation of the number of species existing in nature. New species, or new variants of known species, emerge continuously. The intensive international trade increases the risk that plants infected with Phytophthora are brought into new areas where the indigenous flora can become the victim of these potential new pathogens. Moreover, when crops or ornamentals are grown in areas different from their center of origin, there is always a chance that endemic Phytophthora species discover these new potential hosts. This may result in new diseases and likely in the expansion of the pathogen population. The means to control Phytophthora diseases are limited, but the technologies to detect and identify these plant pathogens are rapidly improving. Molecular diagnostics for faster and more precise identification of species is instrumental for tracking unintended spread of Phytophthora species and as such, supportive of integrated disease management strategies to control Phytophthora diseases.

\section{ACKNOWLEDGMENTS}

Financial support was provided by The Centre for BioSystems Genomics (CBSG) which is part of the Netherlands Genomics Initiative/ Netherlands Organisation for Scientific Research (F. Govers) and by the Dutch Ministry of Agriculture, Nature and Food Quality through an FES program (H. Brouwer). We thank P. J. G. M. de Wit and W. A. Man in 't Veld for discussion and feedback.

\section{LITERATURE CITED}

1. Abad, Z. G., and Abad, J. A. 2003. Advances in the integration of morphological and molecular characterization in the genus Phytophthora: The case of $P$. niederhauseria sp. Nov. (Abstr.) Phytopathology 93(suppl.):S1.

2. Abad, Z. G., Abad, J. A., Coffey, M. D., Oudemans, P. V., Man in 't Veld, W. A., De Gruyter, H., Cunnington, J., and Louws, F. J. 2008. Phytophthora bisheria sp. nov., a new species identified in isolates from the Rosaceous raspberry, rose and strawberry in three continents. Mycologia 100:99-110.

3. Abad, Z. A., Abad, J. A., and Creswell, T. 2006. Species of Phytophthora and Pythium identified in a long term collection from North Carolina. (Abstr.) Phytopathology 96(suppl.):S1.

4. Abad, Z. G., Ivors, K. L., Gallup, C. A., Abad, J. A., and Shew, H. D. 2011. Morphological and molecular characterization of Phytophthora glovera sp. nov. from tobacco in Brazil. Mycologia 103:341-350.

5. Abad, Z. G., Palm, M., Shukl, R., Rice, S., Rascoe, J., Creswell, T., and Nelson, S. 2008. Morphological and molecular identification of eight putative new Phytophthora species from the USA. Third International Workshop Integration of Traditional and Modern Approaches for Investigating the Taxonomy and Evolution, Turin, Italy.

6. Álvarez, I., and Wendel, J. F. 2003. Ribosomal ITS sequences and plant phylogenetic inference. Mol. Phylogenet. Evol. 29:417-434.

7. Aragaki, M., and Uchida, J. Y. 2001. Morphological distinctions between Phytophthora capsici and P. tropicalis sp. nov. Mycologia 93:137-145.

8. Bailey, C. D., Carr, T. G., Harris, S. A., and Hughes, C. E. 2003. Characterization of angiosperm nrDNA poymorphism, paralogy, and pseudogenes. Mol. Phylogenet. Evol. 29:435-455.

9. Balci, Y., Balci, S., Blair, J. E., Park, S. Y., Kang, S., and MacDonald, W. L. 2008. Phytophthora quercetorum sp. nov., a novel species isolated from eastern and north-central USA oak forest soils. Mycol. Res. 112:906-916.

10. Balci, Y., Balci, S., Eggers, J., MacDonald, W. L., Juzwik, J., Long, R. P., and Gottschalk, K. W. 2007. Phytophthora spp. associated with forest soils in eastern and north-central US oak ecosystems. Plant Dis. 91:705-710.

11. Belbahri, L., Moralejo, E., Calmin, G., Oszako, T., Garcia, J. A., Descals, E., and Lefort, F. 2006. Phytophthora polonica, a new species isolated from declining Alnus glutinosa stands in Poland. FEMS Microbiol. Lett. 261:165-174.

12. Bezuidenhout, C. M., Denman, S., Kirk, S. A., Botha, W. J., Mostert, L., and McLeod, A. 2010. Phytophthora taxa associated with cultivated Agathosma, with emphasis on the P. citricola complex and P. capensis sp. nov. Persoonia 25:32-49.

13. Blair, J. E., Coffey, M. D., Park, S.-Y., Geiser, D. M., and Kang, S. 2008. 
A multi-locus phylogeny for Phytophthora utilizing markers derived from complete genome sequences. Fungal Genet. Biol. 45:266-277.

14. Brasier, C. M., Beales, P. A., Kirk, S. A., Denman, S., and Rose, J. 2005. Phytophthora kernoviae sp. nov., an invasive pathogen causing bleeding stem lesions on forest trees and foliar necrosis of ornamentals in the UK. Mycol. Res. 109:853-859.

15. Brasier, C. M., Cooke, D. E. L., and Duncan, J. M. 1999. Origin of a new Phytophthora pathogen through interspecific hybridization. Proc. Natl. Acad. Sci. USA 96:5878-5883.

16. Brasier, C. M., Cooke, D. E. L., Duncan, J. M., and Hansen, E. M. 2003. Multiple new phenotypic taxa from trees and riparian ecosystems in Phytophthora gonapodyides-P. megasperma ITS Clade 6, which tend to be high-temperature tolerant and either inbreeding or sterile. Mycol. Res. 107:277-290

17. Brasier, C. M., Kirk, S. A., Delcan, J., Cooke, D. E. L., Jung, T., and Man in 't Veld, W. A. 2004. Phytophthora alni sp. nov. and its variants: Designation of emerging heteroploid hybrid pathogens spreading on Alnus trees. Mycol. Res. 108:1172-1184.

18. Brasier, C. M., Sanchez-Hernandez, E., and Kirk, S. A. 2003. Phytophthora inundata sp. nov., a part heterothallic pathogen of trees and shrubs in wet or flooded soils. Mycol. Res. 107:477-484.

19. Brasier, C. M., and Webber, J. 2010. Plant pathology: Sudden larch death. Nature 466:824-825.

20. Burgess, T. I., Webster, J. L., Ciampini, J. A., White, D., Hardy, G. E. S., and Stukely, M. J. C. 2009. Re-evaluation of Phytophthora species isolated during 30 years of vegetation health surveys in Western Australia using molecular techniques. Plant Dis. 93:215-223.

21. Chamnanpunt, J., Shan, W.-X., and Tyler, B. M. 2001. High frequency mitotic gene conversion in genetic hybrids of the oomycete Phytophthora sojae. Proc. Natl. Acad. Sci. USA 98:14530-14535.

22. Cooke, D. E. L., Drenth, A., Duncan, J. M., Wagels, G., and Brasier, C. M. 2000. A molecular phylogeny of Phytophthora and related Oomycetes. Fungal Genet. Biol. 30:17-32.

23. Crous, P. W., Groenewald, J. Z., Shivas, R. G., Edwards, J., Seifert, K. A., Alfenas, A. C., Alfenas, R. F., Burgess, T. I., Carnegie, A. J., Hardy, G. E. St. J., Hiscock, N., Hüberli, D., Jung, T., Louis-Seize, G., Okada, G., Pereira, O. L., Stukely, M. J. C., Wang, W., White, G. P., Young, A. J., McTaggart, A. R., Pascoe, I. G., Porter, I. J., and Quaedvlieg, W. 2011. Fungal planet description sheets: 69-91. Persoonia 26:108-156.

24. De Bary, A. 1876. Researches into the nature of the potato fungus Phytophthora infestans. J. Roy. Agric. Soc. Eng. series 212:239-269.

25. De Cock, A. W. A. M., and Lévesque, C. A. 2004. New species of Pythium and Phytophthora. Stud. Mycol. 50:481-487.

26. Dick, M. A., Dobbie, K., Cooke, D. E. L., and Brasier, C. M. 2006. Phytophthora captiosa sp. nov. and $P$. fallax sp. nov. causing crown dieback of Eucalyptus in New Zealand. Mycol. Res. 110:393-404.

27. Dick, M. W. 1989. Phytophthora undulata comb. nov. Mycotaxon 35:449453.

28. Donahoo, R., Blomquist, C. L., Thomas, S. L., Moulton, J. K., Cooke, D. E. L., and Lamour, K. H. 2006. Phytophthora foliorum sp. nov., a new species causing leaf blight of azalea. Mycol. Res. 110:1309-1322.

29. Donahoo, R. S., and Lamour, K. H. 2008. Interspecific hybridization and apomixis between Phytophthora capsici and Phytophthora tropicalis. Mycologia 100:911-920.

30. Duran, A., Gryzenhout, M., Slippers, B., Ahumada, R., Rotella, A., Flores, F., Wingfield, B. D., and Wingfield, M. J. 2008. Phytophthora pinifolia sp. nov. associated with a serious needle disease of Pinus radiata in Chile. Plant Pathol. 57:715-727.

31. Duran, A., Slippers, B., Gryzenhout, M., Ahumada, R., Drenth, A., Wingfield, B. D., and Wingfield, M. J. 2009. DNA-based method for rapid identification of the pine pathogen, Phytophthora pinifolia. FEMS Microbiol. Lett. 298:99-104.

32. Érsek, T., English, J. T., and Schoelz, J. E. 1995. Creation of species hybrids of Phytophthora with modified host ranges by zoospore fusion. Phytopathology 85:1343-1347.

33. Érsek, T., and Nagy, Z. A. 2008. Species hybrids in the genus Phytophthora with emphasis on the alder pathogen Phytophthora alni: A review. Eur. J. Plant Pathol. 122:31-39.

34. Érsek, T., and Ribeiro, O. K. 2010. An annotated list of new Phytophthora species described post 1996. Acta Phytopathol. Hun. 45:251-266.

35. Erwin, D. C., and Ribeiro, O. K. 1996. Phytophthora Diseases Worldwide. American Phytopathological Society, St. Paul, MN

36. Flier, W. G., Grünwald, N. J., Kroon, L. P. N. M., Sturbaum, A. K., Van den Bosch, G. B. M., Garay-Serrano, E., Lozoya-Saldaña, H., Fry, W. E., and Turkensteen, L. J. 2003. The population structure of Phytophthora infestans from the Toluca Valley of central Mexico suggests genetic differentiation between populations from cultivated potato and wild Solanum spp. Phytopathology 93:382-390.

37. Flier, W. G., Grünwald, N. J., Kroon, L. P. N. M., Van den Bosch, G. B.
M., Garay-Serrano, E., Lozoya-Saldaña, H., Bonants, P. J. M., and Turkensteen, L. J. 2002. Phytophthora ipomoeae sp. nov., a new homothallic species causing leaf blight on Ipomoea longipedunculata in the Toluca Valley of central Mexico. Mycol. Res. 106:848-856.

38. Flier, W. G., Kroon, L. P. N. M., Hermansen, A., van Raaij, H. M. G., Speiser, B., Tamm, L., Fuchs, J. G., Lambion, J., Razzaghian, J., Andrivon, D., Wilcockson, S., and Leifert, C. 2007. Genetic structure and pathogenicity of populations of Phytophthora infestans from organic potato crops in France, Norway, Switzerland and the United Kingdom. Plant Pathol. 56:562-572.

39. Göker, M., Voglmayr, H., Riethmüller, A., and Oberwinkler, F. 2007. How do obligate parasites evolve? A multi-gene phylogenetic analysis of downy mildews. Fungal Genet. Biol. 44:105-122.

40. Goodwin, S. B., and Fry, W. E. 1994. Genetic analyses of interspecific hybrids between Phytophthora infestans and Phytophthora mirabilis. Exp. Mycol. 18:20-32.

41. Goss, E. M., Carbone, I., and Grünwald, N. J. 2009. Ancient isolation and independent evolution of the three clonal lineages of the exotic sudden oak death pathogen Phytophthora ramorum. Mol. Ecol. 18:11611174.

42. Goss, E. M., Cardenas, M. C., Myers, K., Forbes, G. A., Fry, W. E., Restrepo, S., and Grünwald, N. J. 2011. The plant pathogen Phytophthora andina emerged via hybridization of an unknown Phytophthora species and the Irish potato famine pathogen, P. infestans. PLoS One 6:e24543.

43. Goss, E. M., Larsen, M., Vercauteren, A., Werres, S., Huengens, K., and Grünwald, N. J. 2011. Phytophthora ramorum in Canada: Evidence for migration within North America and from Europe. Phytopathology 101:166-171.

44. Greslebin, A. G., Hansen, E. M., and Sutton, W. 2007. Phytophthora austrocedrae sp. nov., a new species associated with Austrocedrus chilensis mortality in Patagonia (Argentina). Mycol. Res. 111:308-316.

45. Grünwald, N. J., and Flier, W. G. 2005. Biology of Phytophthora infestans at its center of origin. Annu. Rev. Phytopathol. 43:171-190.

46. Grünwald, N. J., and Goss, A. M. 2011. Evolution and population genetics of exotic and re-emerging pathogens: Novel tools and approaches. Annu. Rev. Phytopathol. 49:249-267.

47. Grünwald, N. J., Martin, F. M., Larsen, M., Sullivan, C., Press, C. M., Coffey, M. D., Hansen, E. M., and Parke, J. L. 2010. PhytophthoraID.org: A sequence based Phytophthora identification tool. Plant Dis. 95:337-342.

48. Grünwald, N. J., Werres, S., Goss, E. M., Taylor, C. R., and Fieland, V. J. 2011. Phytophthora obscura sp. nov., a new species that is a member of the novel Phytophthora subclade 8d. Plant Pathol. Published online: DOI: 10.1111/j.1365-3059.2011.02538.x.

49. Hansen, E. M., Reeser, P. W., Davidson, J. M., Garbelotto, M., Ivors, K., Douhan, L., and Rizzo, D. M. 2003. Phytophthora nemorosa, a new species causing cankers and leaf blight of forest trees in California and Oregon, USA. Mycotaxon 88:129-138.

50. Hansen, E. M., Wilcox, W. F., Reeser, P. W., and Sutton, W. 2009. Phytophthora rosacearum and $P$. sansomeana, new species segregated from the Phytophthora megasperma "complex". Mycologia 101:129-135.

51. Ho, H. H. 2001. Phytophthora oryzo-bladis, a new name for P. fragariae var. oryzo-bladis. Mycotaxon 78:17-21.

52. Hong, C. X., Gallegly, M. E., Browne, G. T., Bhat, R. G., Richardson, P. A., and Kong, P. 2009. The avocado subgroup of Phytophthora citricola constitutes a distinct species, Phytophthora mengei sp. nov. Mycologia 101:833-840.

53. Hong, C. X., Gallegly, M. E., Richardson, P. A., and Kong, P. 2011. Phytophthora pini resurrected to distinct species status. Mycologia 103:351-360.

54. Hong, C. X., Gallegly, M. E., Richardson, P. A., Kong, P., and Moorman, G. W. 2008. Phytophthora irrigata, a new species isolated from irrigation reservoirs and rivers in Eastern United States of America. FEMS Microbiol. Lett. 285:203-211.

55. Hong, C. X., Gallegly, M. E., Richardson, P. A., Kong P., Moorman, G. W., Lea-Cox, J. D., and Ross, D. S. 2010. Phytophthora hydropathica, a new pathogen identified from irrigation water, Rhododendron catawbiense and Kalmia latifolia. Plant Pathol. 59:913-921.

56. Hurtado-Gonzales, O. P., Aragon-Caballero, L. M., Flores-Torres, J. G., Man in 't Veld, W. A., and Lamour, K. H. 2009. Molecular comparison of natural hybrids of Phytophthora nicotianae and P. cactorum infecting loquat trees in Peru and Taiwan. Mycologia 101:496-502.

57. Ilieva, E., Man in 't Veld, W. A., Veenbaas Rijks, W., and Pieters, R. 1998. Phytophthora multivesiculata, a new species causing rot in Cymbidium. Eur. J. Plant Pathol. 104:677-684.

58. Ioos, R., Andrieux, A., Marçais, B., and Frey, P. 2006. Genetic characterization of the natural hybrid species Phytophthora alni as inferred from nuclear and mitochondrial DNA analyses. Fungal Genet. 
Biol. 43:511-529.

59. Jung, T. 2009. Beech decline in Central Europe driven by the interaction between Phytophthora infections and climatic extremes. For. Pathol. 39:73-94.

60. Jung, T., and Burgess, T. I. 2009. Re-evaluation of Phytophthora citricola isolates from multiple woody hosts in Europe and North America reveals a new species, Phytophthora plurivora sp. nov. Persoonia 22:95-110.

61. Jung, T., Cooke, D. E. L., Blaschke, H., Duncan, J. M., and Osswald, W. 1999. Phytophthora quercina sp. nov., causing root rot of European oaks. Mycol. Res. 103:785-798.

62. Jung, T., Hansen, E. M., Winton, L., Osswald, W., and Delatour, C. 2002. Three new species of Phytophthora from European oak forests. Mycol. Res. 106:397-411.

63. Jung, T., and Nechwatal, J. 2008. Phytophthora gallica sp. nov., a new species from rhizosphere soil of declining oak and reed stands in France and Germany. Mycol. Res. 112:1195-1205.

64. Jung, T., Nechwatal, J., Cooke, D. E. L., Hartmann, G., Blaschke, M., Osswald, W. F., Duncan, J. M., and Delatour, C. 2003. Phytophthora pseudosyringae sp. nov., a new species causing root and collar rot of deciduous tree species in Europe. Mycol. Res. 107:772-789.

65. Jung, T., Stukely, M. J. C., Hardy, G. E. S. J., White, D., Paap, T., Dunstan, W. A., and Burgess, T. I. 2011. Multiple new Phytophthora species from ITS Clade 6 associated with natural ecosystems in Australia; evolutionary and ecological implications Persoonia 26:13-39.

66. Knapova, G., and Gisi, U. 2002. Phenotypic and genotypic structure of Phytophthora infestans populations on potato and tomato in France and Switzerland. Plant Pathol. 51:641-653.

67. Ko, W. H., Chang, H. S., Su, H. J., Chen, C. C., and Leu, L. S. 1978. Peronophythoraceae, a new family of Peronosporales. Mycologia 70:380384.

68. Kroon, L. P. N. M., van Raaij, H. M. G., and Flier, W. G. 2010. Inheritance of host specificity in hybrid progeny of the oomycete pathogens Phytophthora infestans and Phytophthora mirabilis. Pages 7389 in: The Genus Phytophthora; Phylogeny, Speciation and Host Specificity. L. P. N. M. Kroon. Wageningen University, Wageningen, The Netherlands.

69. Kroon, L. P. N. M., Bakker, F. T., Van den Bosch, G. B. M., Bonants, P. J. M., and Flier, W. G. 2004. Phylogenetic analysis of Phytophthora species based on mitochondrial and nuclear DNA sequences. Fungal Genet. Biol. 41:766-782.

70. Lee, S. B., and Taylor, J. W. 1992. Phylogeny of 5 fungus-like protoctistan Phytophthora species, inferred from the internal transcribed spacers of ribosomal DNA. Mol. Biol. Evol. 9:636-653.

71. Leonian, L. H. 1930. Differential growth of Phytophthora under the action of malachite green. Am. J. Bot. XVII:671-677.

72. Lévesque, C. A., and De Cock, A. W. A. M. 2004. Molecular phylogeny and taxonomy of the genus Pythium. Mycol. Res. 108:1363-1383.

73. Man in 't Veld, W. A. 2007. Gene flow analysis demonstrates that Phytophthora fragariae var. rubi constitutes a distinct species, Phytophthora rubi comb. nov. Mycologia 99:222-226.

74. Man in 't Veld, W. A., De Cock, A. W. A. M., Ilieva, E., and Lévesque, C. A. 2002. Gene flow analysis of Phytophthora porri reveals a new species: Phytophthora brassicae sp. nov. Eur. J. Plant Pathol. 108:51-62.

75. Man in 't Veld, W. A., De Cock, A. W. A. M., and Summerbell, R. C. 2007. Natural hybrids of resident and introduced Phytophthora species proliferating on multiple new hosts. Eur. J. Plant Pathol. 117:25-33.

76. Man in 't Veld, W. A., Rosendahl, K. C. H. M., Brouwer, H., and De Cock, A. W. A. M. 2011. Phytophthora gemini sp. nov., a new species isolated from the halophilic plant Zostera marina in the Netherlands. Fung. Biol. 115:724-732.

77. Man in 't Veld, W. A., Veenbaas-Rijks, W. J., Ilieva, E., De Cock, A. W. A. M., Bonants, P. J. M., and Pieters, R. 1998. Natural hybrids of Phytophthora nicotianae and Phytophthora cactorum demonstrated by isozyme analysis and random amplified polymorphic DNA. Phytopathology 88:922-929.

78. Martin, F. N., and Tooley, P. W. 2003. Phylogenetic relationships among Phytophthora species inferred from sequence analysis of mitochondrially encoded cytochrome oxidase I and II genes. Mycologia 95:269284.

79. Martin, F. N., and Tooley, P. W. 2003. Phylogenetic relationships of Phytophthora ramorum, P. nemorosa, and P. pseudosyringae, three species recovered from areas in California with sudden oak death. Mycol. Res. 107:1379-1391.

80. Maseko, B., Burgess, T. I., Coutinhon T. A., and Wingfield, M. J. 2007. Two new Phytophthora species from South African Eucalyptus plantations. Mycol. Res. 111:1321-1338.

81. May, K. J., Drenth, A., and Irwin, J. A. G. 2003. Interspecific hybrids between the homothallic Phytophthora sojae and Phytophthora vignae. Australas. Plant Pathol. 32:353-359.
82. Mirabolfathy, M., Cooke, D. E. L., Duncan, J. M., Williams, N. A., Ershad, D., and Alizadeh, A. 2001. Phytophthora pistaciae sp. nov. and P. melonis: The principal causes of pistachio gummosis in Iran. Mycol. Res. 105:1166-1175.

83. Mostowfizadeh-Ghalamfarsa, R., Cooke, D. E. L., and Banihashemi, Z. 2008. Phytophthora parsiana sp. nov., a new high-temperature tolerant species. Mycol. Res. 112:783-794.

84. Naher, M., Motohash, K., Watanabe, H., Chikuo, Y., Senda, M., Suga, H., Brasier, C., and Kageyama, K. 2011. Phytophthora chrysanthemi sp. nov., a new species causing root rot of chrysanthemum in Japan. Mycol. Prog. 10:21-31.

85. Nechwatal, J., and Mendgen, K. 2006. Widespread detection of Phytophthora taxon Salixsoil in the littoral zone of Lake Constance, Germany. Eur. J. Plant Pathol. 114:261-264.

86. Nelson, S. C., and Abad, Z. G. 2010. Phytophthora morindae, a new species causing black flag disease on noni (Morinda citrifolia L.) in Hawaii. Mycologia 102:122-134.

87. Nirenberg, H. I., Gerlach, W. F., and Gräfenhan, T. 2009. Phytophthora Xpelgrandis, a new natural hybrid pathogenic to Pelargonium grandiflorum hort. Mycologia 101:220-231.

88. Oliva, R. F., Kroon, L. P. N. M., Chacon, G., Flier, W. G., Ristaino, J. B., and Forbes, G. A. 2010. Phytophthora andina sp. nov., a newly identified heterothallic pathogen of solanaceous hosts in the Andean highlands. Plant Pathol. 59:613-625.

89. Oudemans, P., and Coffey, M. D. 1991. A revised systematics of 12 papillate Phytophthora species based on isozyme analysis. Mycol. Res. 95:1025-1046.

90. Park, J., Park, B., Veeraraghavan, N., Jung, K., Lee, Y.-H., Blair, J. E., Geiser, D. M., Isard, S., Mansfield, M. A., Nikolaeva, E., Park, S.-Y., Russo, J., Kim, S. H., Greene, M., Ivors, K. L., Balci, Y., Peiman, M., Erwin, D. C., Coffey, M. D., Rossman, A., Farr, D., Cline, E., Grünwald, N. J., Luster, D. G., Schrandt, J., Martin, F., Ribeiro, O. K., Makalowska, I., and Kang, S. 2008. Phytophthora database: A forensic database supporting the identification and monitoring of Phytophthora. Plant Dis. 92:966-972.

91. Petersen, H. E. 1910. An account of Danish freshwater phycomycetes, with biological and systematic remarks. Ann. Mycol. 8:494-560.

92. Polashock, J. J., Vaiciunas, J., and Oudemans, P. V. 2005. Identification of a new Phytophthora species causing root and runner rot of cranberry in New Jersey. Phytopathology 95:1237-1243.

93. Purvis, A. I., Pipe, N. D., Day, J. P., Shattock, R. C., Shaw, D. S., and Assinder, S. J. 2001. AFLP and RFLP (RG57) fingerprints can give conflicting evidence about the relatedness of isolates of Phytophthora infestans. Mycol. Res. 105:1321-1330.

94. Rea, A. J., Burgess, T. I., Stukely, M. J. C., Hardy, G. E. St. J., and Jung, T. 2011. Two novel and potentially endemic species of Phytophthora associated with episodic dieback of Kwongan vegetation in the southwest of Western Australia. Plant Pathol. 60:1055-1068. DOI: 10.1111/ j.1365-3059.2011.02463.x.

95. Rea, A. J., Jung, T., Burgess, T. I., Stukely, M. J. C., and Hardy, G. E. St. J. 2010. Phytophthora elongata sp. nov., a novel pathogen from the Eucalyptus marginata forest of Western Australia. Australas. Plant Pathol. 39:477-491.

96. Reeser, P. W., Hansen, E. M., and Sutton, W. 2007. Phytophthora siskiyouensis, a new species from soil, water, myrtlewood (Umbellularia californica) and tanoak (Lithocarpus densiflorus) in southwestern Oregon. Mycologia 99:639-643.

97. Rizzo, D. M., Garbelotto, M., Davidson, J. M., Slaughter, G. W., and Koike, S. T. 2002. Phytophthora ramorum as the cause of extensive mortality of Quercus spp. and Lithocarpus densiflorus in California. Plant Dis. 86:205-214.

98. Saude, C., Hurtado-Gonzales, O. P., Lamour, K. H., and Hausbeck, M. K. 2008. Occurrence and characterization of a Phytophthora sp. pathogenic to asparagus (Asparagus officinalis) in Michigan. Phytopathology 98:1075-1083.

99. Scott, P. M., Burgess, T. I., Barber, P. A., Shearer, B. L., Stukely, M. J. C., Hardy, G. E. S., and Jung, T. 2009. Phytophthora multivora sp. nov., a new species recovered from declining Eucalyptus, Banksia, Agonis and other plant species in Western Australia. Persoonia 22:1-13.

100. Stamps, D. J., Waterhouse, G. M., Newhook, F. J., and Hall, G. S. 1990. Revised tabular key to the species of Phytophthora. Mycol. Papers $162: 1-28$.

101. Streito, J. C., Legrand, P., Tabary, F., and De Villartay, G. J. 2002. Phytophthora disease of alder (Alnus glutinosa) in France: Investigations between 1995 and 1999. For. Pathol. 32:179-191.

102. Van der Lee, T., De Witte, I., Drenth, A., Alfonso, C., and Govers, F. 1997. AFLP linkage map of the oomycete Phytophthora infestans. Fungal Genet. Biol. 21:278-291.

103. Vettraino, A. M., Brasier, C. M., Brown, A. V., and Vannini, A. 2011. 
Phytophthora himalsilva sp. nov. an unusually phenotypically variable species from a remote forest in Nepal. Fungal Biol. 115:275-287.

104. Waterhouse, G. M. 1963. Key to the species Phytophthora de Bary. Mycological paper No. 92. CMI, Kew, UK.

105. Werres, S., Marwitz, R., Man in 't Veld, W. A., De Cock, A. W. A. M., Bonants, P. J. M., De Weerdt, M., Themann, K., Ilieva, E., and Baayen,
R. P. 2001. Phytophthora ramorum sp. nov., a new pathogen on Rhododendron and Viburnum. Mycol. Res. 105:1155-1165.

106. Werres, S., Marwitz, R., Poerschke, U., and Themann, K. 2001. A longterm study of Phytophthora species in Germany. 2. Phytophthora species which could not be definitely identified. Z. Pflanzenk. Pflanzen. 108:121-135.

\section{Erratum}

The hosts listed in Table 3 have been corrected. Changes to this article were made on May 9, 2014. 